\title{
Holocene dynamics in the Bering Strait inflow to the Arctic and the Beaufort Gyre circulation based on sedimentary records from the Chukchi Sea
}

\author{
Masanobu Yamamoto ${ }^{1,2,3}$, Seung-Il Nam ${ }^{4}$, Leonid Polyak ${ }^{5}$, Daisuke Kobayashi ${ }^{3}$, Kenta Suzuki $^{3}$ Tomohisa Irino $^{1,3}$, \\ and Koji Shimada ${ }^{6}$ \\ ${ }^{1}$ Faculty of Environmental Earth Science, Hokkaido University, Kita-10, Nishi-5, Kita-ku, Sapporo 060-0810, Japan \\ ${ }^{2}$ Global Institution for Collaborative Research and Education, Hokkaido University, Kita-10, Nishi-5, Kita-ku, \\ Sapporo 060-0810, Japan \\ ${ }^{3}$ Gradute School of Environmental Science, Hokkaido University, Kita-10, Nishi-5, Kita-ku, Sapporo 060-0810, Japan \\ ${ }^{4}$ Korea Polar Research Institute, 26 Songdomirae-ro, Yeonsu-gu, Incheon 21990, Republic of Korea \\ ${ }^{5}$ Byrd Polar and Climate Research Center, The Ohio State University, Columbus, OH 43210, USA \\ ${ }^{6}$ Tokyo University of Marine Science and Technology, 4-5-7, Konan, Minato-ku, Tokyo 108-8477, Japan
}

Correspondence to: Masanobu Yamamoto (myama@ees.hokudai.ac.jp)

Received: 1 April 2017 - Discussion started: 24 April 2017

Revised: 21 July 2017 - Accepted: 9 August 2017 - Published: 8 September 2017

\begin{abstract}
The Beaufort Gyre (BG) and the Bering Strait inflow (BSI) are important elements of the Arctic Ocean circulation system and major controls on the distribution of Arctic sea ice. We report records of the quartz / feldspar and chlorite / illite ratios in three sediment cores from the northern Chukchi Sea, providing insights into the long-term dynamics of the BG circulation and the BSI during the Holocene. The quartz / feldspar ratio, interpreted as a proxy of the BG strength, gradually decreased during the Holocene, suggesting a long-term decline in the BG strength, consistent with an orbitally controlled decrease in summer insolation. We propose that the $\mathrm{BG}$ rotation weakened as a result of the increasing stability of sea-ice cover at the margins of the Canada Basin, driven by decreasing insolation. Millennial to multi-centennial variability in the quartz / feldspar ratio (the BG circulation) is consistent with fluctuations in solar irradiance, suggesting that solar activity affected the BG strength on these timescales. The BSI approximation by the chlorite / illite record, despite a considerable geographic variability, consistently shows intensified flow from the Bering Sea to the Arctic during the middle Holocene, which is attributed primarily to the effect of higher atmospheric pressure over the Aleutian Basin. The intensified BSI was associated with decrease in sea-ice concentrations and increase in marine production, as indicated by biomarker concentrations, sug-
\end{abstract}

gesting a major influence of the BSI on sea-ice and biological conditions in the Chukchi Sea. Multi-century to millennial fluctuations, presumably controlled by solar activity, were also identified in a proxy-based BSI record characterized by the highest age resolution.

\section{Introduction}

The Arctic currently faces rapid climate change caused by global warming (e.g., Screen and Simmonds, 2010; Harada, 2016). Changes in the current system of the Arctic Ocean regulate the state of Arctic sea ice and are involved in global processes via ice albedo feedback and the delivery of freshwater to the North Atlantic Ocean (Miller et al., 2010; Screen and Simmonds, 2010). The most significant consequence of this climate change during recent decades is the retreat of summer sea ice in the Pacific sector of the Arctic (e.g., Shimada et al., 2006; Harada, 2016, and references therein). Inflow of warm Pacific water through the Bering Strait (hereafter Bering Strait inflow - BSI) is suggested to have caused catastrophic changes in sea-ice stability in the western Arctic Ocean (Shimada et al., 2006). Comprehending these changes requires the investigation of a longer-term history of circulation in the western Arctic and its relationship to atmospheric 


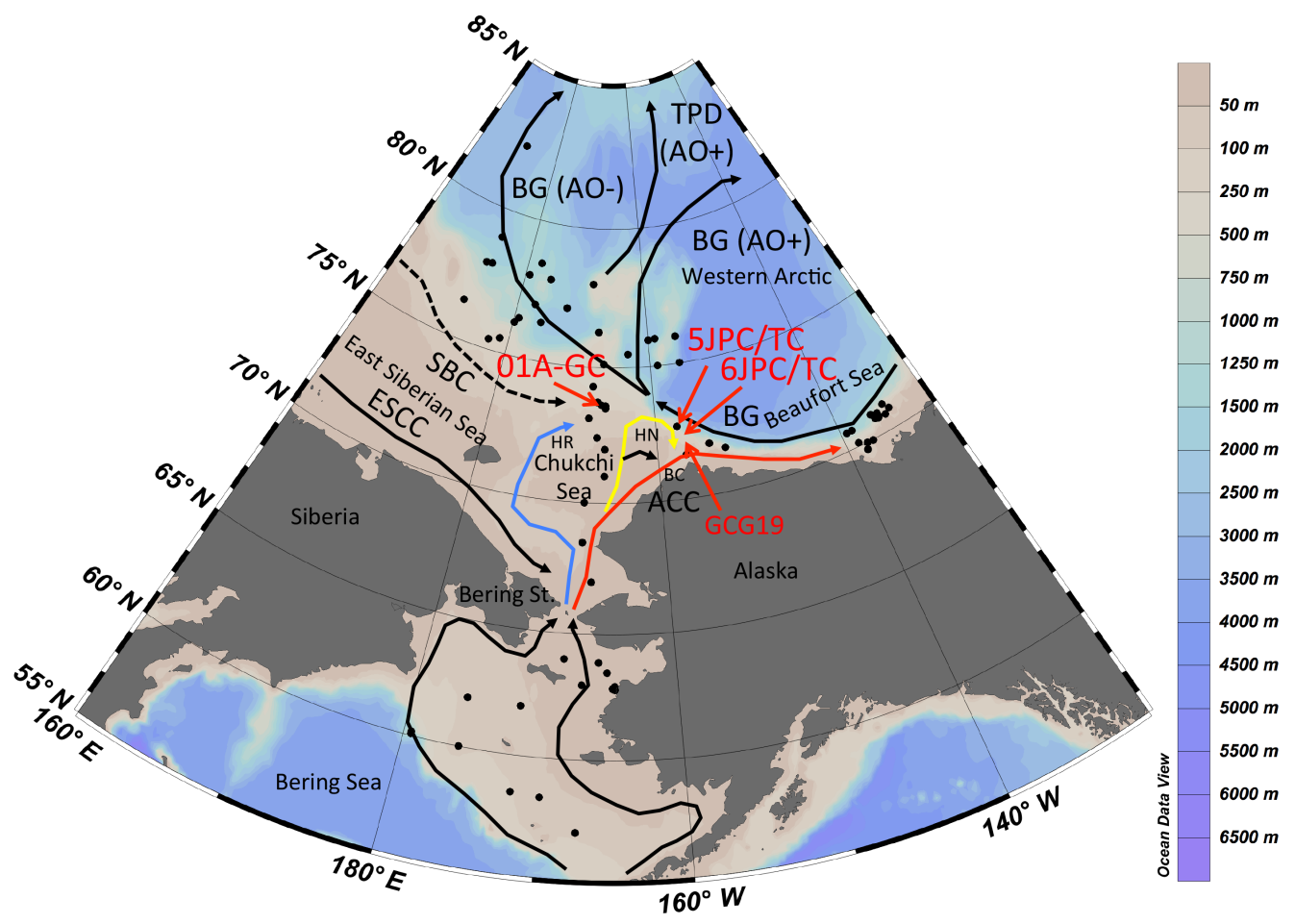

Figure 1. Index map showing location of cores ARA02B 01A-GC (this study), HLY0501-05JPC/TC (this study and Farmer et al., 2011), HLY0501-06JPC (this study and Ortiz et al., 2009), and HLY0205-GGC19 (Farmer et al., 2011), as well as surface sediment samples (Kobayashi et al., 2016, with additions). The positions of added surface sediments are listed in Supplement Table S1. BC: Barrow Canyon; HN: Hanna Shoal; HR: Herald Shoal. BG: Beaufort Gyre; ACC: Alaskan Coastal Current; SBC: Subsurface Boundary Current; ESCC: East Siberian Coastal Current; TPD: Transpolar Drift. Red, yellow, and blue arrows indicate BSI branches. AO+ and AO- indicate circulation in the positive and negative phases of the Arctic Oscillation, respectively.

forcings. Within this context, the Chukchi Sea is a key region to understand the western Arctic current system as it is located at the crossroads of the BSI and the Beaufort Gyre (BG) circulation in the western Arctic Ocean (Fig. 1) (e.g., Winsor and Chapman, 2004; Weingartner et al., 2005).

In this paper we apply mineralogical proxies of the BG and BSI to sediment cores with a century-scale resolution from the northern margin of the Chukchi shelf. The generated record provides a new understanding of changes in the BG circulation and BSI strength during most of the Holocene (last $\sim 9 \mathrm{kyr}$ ). We discuss the possible causes and forcings of the BG and BSI variability, as well as its relationship to seaice history and biological production in the western Arctic.

\section{Background information}

\subsection{Oceanographic settings}

The wind-driven surface current system of the Arctic Ocean consists of the BG and the Transpolar Drift (TPD) (Proshutinsky and Johnson, 1997; Rigor et al., 2002). This circulation is controlled by the atmospheric system known as the Arctic Oscillation (AO) (Rigor et al., 2002). When the $\mathrm{AO}$ is in the positive phase, the BG shrinks back into the
Beaufort Sea, the TPD expands to the western Arctic Ocean, and the sea-ice transport from the eastern Arctic to the Atlantic Ocean is intensified. When the AO is in negative phase, the BG expands, the TPD is limited to the eastern Arctic, and sea ice is exported efficiently from the Canada Basin to the eastern Arctic. Thus, sea-ice distribution is closely related to the current system.

A dramatic strengthening of the BG circulation occurred during the last two decades (Shimada et al., 2006; Giles et al., 2012). This change was attributed to a recent reduction in sea-ice cover along the margin of the Canada Basin, which caused a more efficient transfer of the wind momentum to the ice and underlying waters in the BG (Shimada et al., 2006). The delayed development of sea ice in winter enhanced the western branch of the Pacific Summer Water across the Chukchi Sea. This anomalous heat flux into the western part of the Canada Basin retarded sea-ice formation during winter, thus further accelerating overall sea-ice reduction.

The BSI, an important carrier of heat and freshwater to the Arctic, transports the Pacific water to and across the Chukchi Sea and interacts with the BG circulation at the Chukchi shelf margin (e.g., Shimada et al., 2006). Mooring data suggest that an increase in the BSI volume by 
$\sim 50 \%$ from $2001(\sim 0.7 \mathrm{~Sv})$ to $2011(\sim 1.1 \mathrm{~Sv})$ has driven an according increase in the heat flux from $\sim 3 \times 10^{20}$ to $\sim 5 \times 10^{20} \mathrm{~J}$ (Woodgate et al., 2012). After passing the Bering Strait the BSI flows in three major branches. One branch, the Alaskan Coastal Current (ACC), runs northeastward along the Alaskan coast as a buoyancy-driven boundary current (Red arrow in Fig. 1; Shimada et al., 2001; Pickart, 2004; Weingartner et al., 2005). The second, central branch follows a seafloor depression between Herald and Hanna shoals, then turns eastward and merges with the ACC (Yellow arrow in Fig. 1; Winsor and Chapman, 2004; Weingartner et al., 2005). The third branch flows northwestward, especially when easterly winds prevent the ACC from flowing (Winsor and Chapman, 2004). This branch may then turn eastward along the shelf break (Blue arrow in Fig. 1; Pickart et al., 2010).

The BSI is driven by a northward dip in sea level between the North Pacific and the Arctic Ocean (Shtokman, 1957; Coachman and Aagaard, 1966). There has been a longstanding debate whether this dipping is primarily controlled by steric difference (Stigebrandt, 1984) or wind-driven circulations (Gudkovitch, 1962). Stigebrandt (1984) assumed that the salinity difference between the Pacific and Atlantic oceans causes the steric height difference between the Bering Sea and the Arctic Ocean. Aagaard et al. (2006) argued that the local salinity in the northern Bering Sea controlled the BSI, although wind can considerably modify the BSI on a seasonal timescale. De Boer and Nof (2004) proposed a model by which the mean sea level difference along the strait is set up by the global winds, particularly the strong subantarctic westerlies.

Recently, a conceptual model of the BSI controls has been developed based on a decade of oceanographic observations (Danielson et al., 2014). According to this model, storms centered over the Bering Sea excite continental shelf waves on the eastern Bering shelf that intensify the BSI on synoptic timescales, but the integrated effect of these storms tends to decrease the BSI on annual to decadal timescales. At the same time, an eastward shift and overall strengthening of the Aleutian Low pressure center during the period between 2000-2005 and 2005-2011 increased the sea level pressure in the Aleutian Basin south of the Bering Strait by $5 \mathrm{hPa}$, in contrast to the overall decreased pressure of the Aleutian Low system, thus decreasing the water column density through isopycnal uplift by weaker Ekman suction. This change thereby raised the dynamic sea surface height by $4.2 \mathrm{~m}$ along the Bering Strait pressure gradient, resulting in the BSI increase by $4.5 \mathrm{~cm} \mathrm{~s}^{-1}$, or $0.2 \mathrm{~Sv}$ (calculated based on the cross-section area of $4.25 \times 10^{6} \mathrm{~m}^{2}$ ). This increase constitutes about a quarter of the average long-term BSI volume of $\sim 0.8 \mathrm{~Sv}$ (Roach et al., 1995). Such a large contribution clearly identifies changes in the Aleutian Low strength and position as a key factor regulating the BSI on interannual timescales.
The BSI also transports nutrients from the Pacific to the Arctic. A rough estimation suggests that the BSI waters significantly contribute to marine production in the Arctic (Yamamoto-Kawai et al., 2006). High marine production in the Chukchi Sea of up to $400 \mathrm{~g} \mathrm{C} \mathrm{m}^{-2} \mathrm{y}^{-1}$ in part is thought to reflect the high nutrient fluxes by the BSI (Walsh and Dieterle, 1994; Sakshaug, 2004). A recent enhancement of biological productivity and the biological pump in the Beaufort and Chukchi seas has been associated with the retreat of sea ice (summarized by Harada, 2016). This phenomenon is attributed to an increase in irradiance in the water column (Frey et al., 2011; Lee and Whitledge, 2005), wind-induced mixing that replenishes sea surface nutrients (Carmack et al., 2006), and their combination (Nishino et al., 2009). However, the nutrient flux into the Arctic Ocean was not evaluated in this context. The investigation of BSI intensity and marine production during the Holocene will be useful to understand ongoing changes in marine production in the Arctic Ocean.

\subsection{Mineral distribution in the Chukchi Sea sediments}

Spatial variation in mineral composition of surficial sediments along the western Arctic margin has been investigated in a number of studies using different methodological approaches but showing an overall consistent picture (e.g., Naidu et al., 1982; Naidu and Mowatt, 1983; Wahsner et al., 1999; Kalinenko, 2001; Viscosi-Shirley et al., 2003; Darby et al., 2011; Kobayashi et al., 2016). A recent study of mineral distribution in sediments from the Chukchi Sea and adjacent areas of the Arctic Ocean and the Bering Sea suggests that the quartz / feldspar $(\mathrm{Q} / \mathrm{F})$ ratio is higher on the North American than on the Siberian side of the western Arctic (Fig. 2; Kobayashi et al., 2016). These results are consistent with earlier studies including mineral determinations of shelf sediments and adjacent coasts (Vogt, 1997; Stein, 2008). Darby et al. (2011) show a trend of a decreasing Q / F ratio in dirty sea ice from the North American margin to the Chukchi Sea and further to the East Siberian Sea. This zonal gradient of the Q / F ratio suggests that quartz-rich but feldspar-poor sediments are derived from the North American margin by the BG circulation, whereas feldspar-rich sediments are delivered to the Chukchi Sea from the Siberian margin by currents along the East Siberian slope (Kobayashi et al., 2016). Thus, this ratio can be used as a provenance index for the BG circulation reflecting changes in its intensity in sediment-core records (Kobayashi et al., 2016).

Kaolinite is generally a minor component of clays in the western Arctic but relatively abundant in the Northwind Ridge and Mackenzie Delta areas where the BG circulation exerts an influence (Naidu and Mowatt, 1983; Kobayashi et al., 2016). Kaolinite in the Northwind Ridge originated from ancient rocks exposed on the North Slope and was delivered by water or sea ice via the Beaufort Gyre circulation (Kobayashi et al., 2016). 

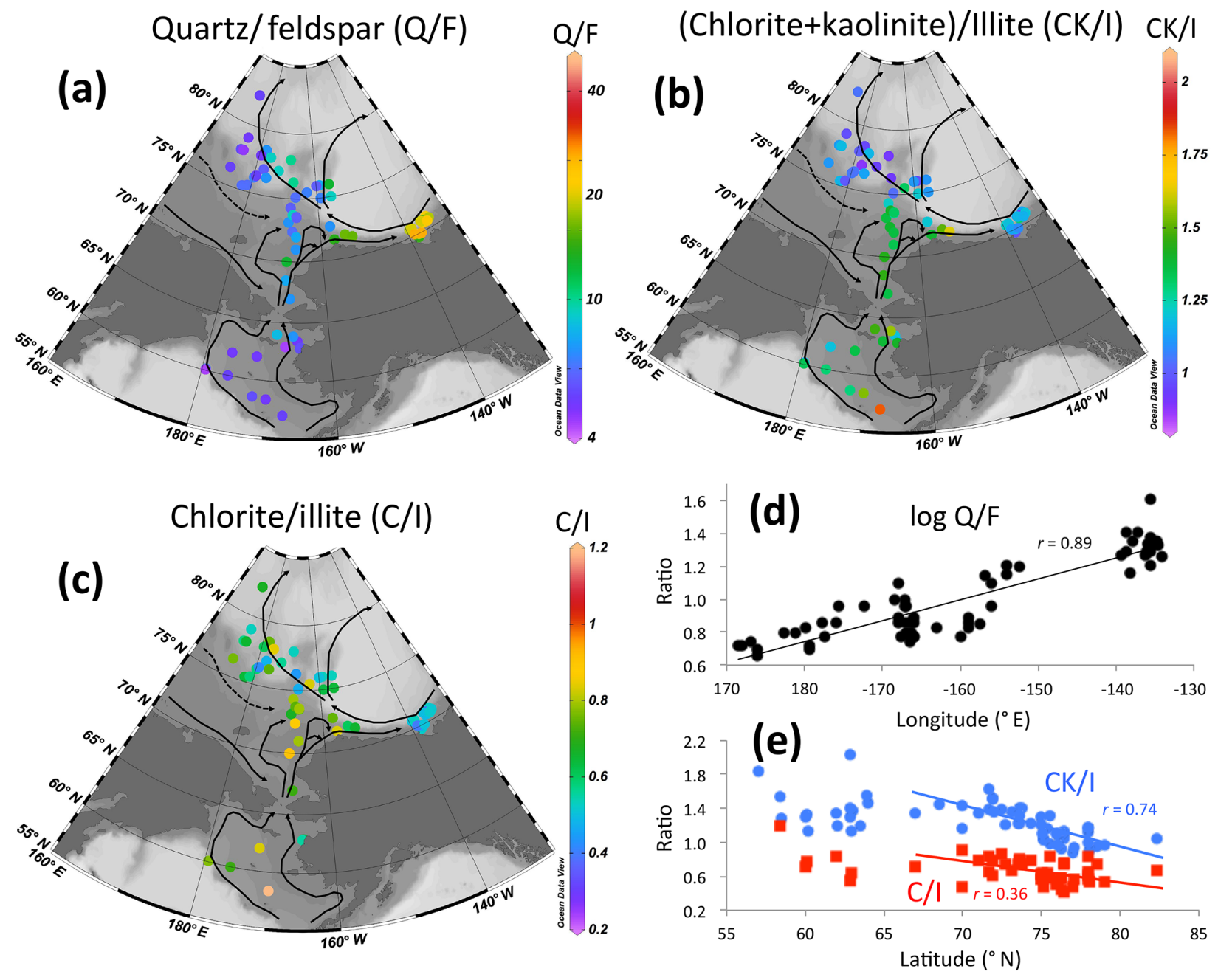

Figure 2. Spatial distributions of the diffraction intensity ratios of (a) feldspar to quartz $(\mathrm{Q} / \mathrm{F})$ and (b) chlorite + kaolinite and (c) chlorite to illite (CK / I and C / I, respectively) of bulk sediments; (d) the longitudinal distribution of the Q / F ratio in the western Arctic ( $>65^{\circ} \mathrm{N}$ ) and (e) the latitudinal distribution of the CK / I and C / I ratios in the Bering Sea and the western Arctic $\left(>150^{\circ} \mathrm{W}\right)$. The C / I ratio could not be determined in some coarse-grained sediment samples. Data from Kobayashi et al. (2016) with additions for the Beaufort Sea (See Supplement Table S1 in more detail). The regression lines in panel (e) show the geographic trends in mineral proxy distribution for the Chukchi Sea. The Bering Sea sediments do not show a systematic pattern, probably reflecting multiple sources of chlorite, such as the Yukon River, Aleutian Islands, etc. The enlarged maps of the Mackenzie River delta and Yukon River estuary are shown in Supplement Figs. S1 and S2.

Kobayashi et al. (2016) also indicate that both the (chlorite + kaolinite $) /$ illite and chlorite / illite ratios $(\mathrm{CK} / \mathrm{I}$ and $\mathrm{C} / \mathrm{I}$ ratios, respectively) are higher in the Bering Sea and decrease northward throughout the Chukchi Sea, reflecting the diminishing strength of the BSI (Fig. 2). These results are consistent with earlier studies showing that illite is a common clay mineral in Arctic sediments (Kalinenko, 2001; Darby et al., 2011), whereas chlorite is more abundant in the Bering Sea and the Chukchi shelf areas influenced by the BSI (Naidu and Mowatt, 1983; Kalinenko, 2001; Nwaodua et al., 2014; Kobayashi et al., 2016). Chlorite occurs abundantly near the Bering Sea coasts of Alaska, Canada, and the Aleutian Islands (Griffin and Goldberg, 1963). The chlorite / illite ratio is higher in the bed load of rivers and deltaic sediments from southwestern Alaska than from northern Alaska and East Siberia, reflecting differences in the geology of the drainage basins (Naidu and Mowatt, 1983). Because chlorite grains are more mobile than illite grains under conditions of intense hydrodynamic activity, chlorite grains are transported a long distance from the northern Bering Sea to the Chukchi Sea via the Bering Strait (Kalinenko, 2001). In the surface sediments of the Chukchi Sea, the CK / I ratio shows a good correlation with the $\mathrm{C} / \mathrm{I}$ ratio, indicating that both ratios can be used as a provenance index for the BSI (Kobayashi et al., 2016).

Ortiz et al. (2009) constructed the first chlorite-based Holocene record of the BSI by quantifying the total chlo- 
rite plus muscovite abundance based on diffuse spectral reflectance of sediments from a northeastern Chukchi Sea core. The record shows a prominent intensification of the BSI in the middle Holocene. However, a record from just one site is clearly insufficient to characterize sedimentation and circulation history in such a complex area. More records of mineral proxy distribution covering various oceanographic and depositional environments are needed to further our understanding of the evolution of the BSI.

The Holocene dynamics of the BG circulation is also poorly understood. A study of sediment cores from the northeastern Chukchi slope identified centennial- to millennialscale variability in the occurrence of Siberian iron oxide grains presumably delivered via the BG (Darby et al., 2012). However, transport of these grains depends not only on the BG but also on circulation and ice conditions in the Eurasian basin, which complicates the interpretation and necessitates further proxy studies of the BG history.

\section{Samples and methods}

\subsection{Coring and sampling}

This study uses three sediment cores from the northern and northeastern margins of the Chukchi Sea: ARA02B 01AGC (gravity core; $563 \mathrm{~cm}$ long; $73^{\circ} 37.89^{\prime} \mathrm{N}, 166^{\circ} 30.98^{\prime} \mathrm{W}$ ), HLY0501-05JPC/TC (jumbo piston core/trigger; $1648 \mathrm{~cm}$ long; $72^{\circ} 41.68^{\prime} \mathrm{N}, 157^{\circ} 31.20^{\prime} \mathrm{W}$ ), and HLY0501-06JPC ( $1554 \mathrm{~cm}$ long; $72^{\circ} 30.71^{\prime} \mathrm{N}, 157^{\circ} 02.08^{\prime} \mathrm{W}$ ) collected from $111 \mathrm{~m}, 462 \mathrm{~m}$, and 673 water depth, respectively (Fig. 1). The sediments in 01A-GC and in the Holocene part of 05JPC/TC $(0-1300 \mathrm{~cm})$ and $06 \mathrm{JPC}(0-935 \mathrm{~cm})$ consist predominantly of homogeneous clayey silt (fine-grained unit). This unit of cores 05JPC and 06JPC is underlain by a more complex lithostratigraphy with laminations and coarse ice-rafted debris indicative of glaciomarine environments affected by glacial/deglacial processes ("glaciomarine unit"; McKay et al., 2008; Lisé-Pronovost et al., 2009; Polyak et al., 2009).

In total 110 samples were collected for mineralogical analysis from core $01 \mathrm{~A}-\mathrm{GC}$ at intervals averaging $5 \mathrm{~cm}$, equivalent to approximately 80-90 years (see chronology description below), down to a depth of $545 \mathrm{~cm}$ (ca. $9.3 \mathrm{ka} \mathrm{BP}$ ). In core 05JPC/TC, 44 samples were collected from finegrained unit at intervals averaging $30 \mathrm{~cm}$ (equivalent to approximately 210-220 years) down to a depth of $1286 \mathrm{~cm}$ (ca. $9.3 \mathrm{ka}$ ) and 7 samples were collected from the underlying glaciomarine sediments. In core 06JPC, 79 samples were collected from fine-grained unit at intervals of $10 \mathrm{~cm}$ (equivalent to approximately 90 years) down to a depth of $937 \mathrm{~cm}$ (ca. $8.0 \mathrm{ka}$ ) and 46 samples were collected from the underlying glaciomarine unit.

We also analyzed 16 surface sediment samples $(0-1 \mathrm{~cm})$ from the eastern Beaufort Sea near the Mackenzie River delta and 3 surface sediment samples from the western Beaufort Sea to fill the gaps in the dataset of Kobayashi et al. (2016)
(Fig. 2). These samples were obtained during the RV Araon cruises in 2013 and 2014 (ARA04C and ARA05C, respectively; Supplement Table S1).

\subsection{Chronology}

Age for core 01A-GC was constrained by seven accelerator mass spectrometry (AMS) ${ }^{14} \mathrm{C}$ ages of mollusc shells (Supplement Table S2; Stein et al., 2017). The core top in ARA 01-GC may not represent the modern age due to some sediment loss in the coring process. This is indicated by the absence of oxidized brown sediment at the core top, as opposed to samples from a multi-corer collected at the same site. Nevertheless, we believe that the top of 01-GC is close to the sediment surface based on the biomarker distribution. $\mathrm{IP}_{25}$ and brassicasterols show a downward decreasing trend in their concentrations in the top $10 \mathrm{~cm}$ (Stein et al., 2017). We suppose that this indicates their degradation with burial. A similar extent of brassicasterol concentration decrease occurs also in some of the deeper intervals, but it is unique for the upper $\sim 200 \mathrm{~cm}$, while the IP25 decrease at the top is unique for the entire record. Therefore, the core top of 01AGC was assumed to represent sediment surface in the agedepth model. ${ }^{14} \mathrm{C}$ ages were converted to calendar ages using the CALIB7.0 program and marine13 dataset (Reimer et al., 2013). Local reservoir correction $(\Delta R)$ for $01 \mathrm{~A}-\mathrm{GC}$ sited in surface waters was assumed to be 500 years (McNeely et al., 2006; Darby et al., 2012). The age model was constructed by linear interpolation between the ${ }^{14} \mathrm{C}$ datings $(3.1-8.6 \mathrm{ka})$. Ages below the dated range were extrapolated to the bottom of the core $(9.3 \mathrm{ka})$.

In core $05 \mathrm{JPC} / \mathrm{TC}$, age was constrained by six AMS ${ }^{14} \mathrm{C}$ ages of mollusc shells from core 05JPC (Supplement Table S2; Barletta et al., 2008; Darby et al., 2009). Local reservoir correction $(\Delta R)$ was assumed to be 0 years as the core site is washed by Atlantic intermediate water (Darby et al., 2012). Concurrent age constraints for 05JPC were provided by ${ }^{210} \mathrm{~Pb}$ determinations in the upper part (05TC) and paleomagnetic analysis (Barletta et al., 2008; McKay et al., 2008). The age model for core 05JPC/TC was constructed by linear interpolation between the ${ }^{14} \mathrm{C}$ datings $(2.4-7.7 \mathrm{ka})$ as well as the assumed modern age of the 05TC top, with the assumption that the offset of JPC to TC is $75 \mathrm{~cm}$ (Darby et al., 2009). Ages below the dated range were extrapolated to the bottom of the homogeneous fine-grained unit at $1300 \mathrm{~cm}(9.4 \mathrm{ka})$.

In core 06JPC, age was tentatively constrained by 10 paleo-intensity datums based on regional paleomagnetic chronology and a ${ }^{14} \mathrm{C}$ age of benthic foraminifera $(8.16 \mathrm{ka}$ at $918 \mathrm{~cm}$ ) (Supplement Table S2; Lisé-Pronovost et al., 2009), with the assumption that the offset of JPC to TC is $147 \mathrm{~cm}$ (Ortiz et al., 2009). The age model for core 06JPC was constructed by linear interpolation between the paleo-intensity datums $(2.0-7.9 \mathrm{ka})$. 


\subsection{X-ray diffractometer mineralogy}

Mineral composition was analyzed on an MX-Labo Xray diffractometer (XRD) equipped with a $\mathrm{CuK} \alpha$ tube and monochromator. The tube voltage and current were $40 \mathrm{kV}$ and $20 \mathrm{~mA}$, respectively. Scanning speed was $4^{\circ} 2 \theta \mathrm{min}^{-1}$, and the data-sampling step was $0.02^{\circ} 2 \theta$. Each powdered sample was mounted on a glass holder with a random orientation and X-rayed from 2 to $40^{\circ} 2 \theta$. An additional precise scan with a scanning speed of $0.2^{\circ} 2 \theta \mathrm{min}^{-1}$ and sampling step of $0.01^{\circ} 2 \theta$ from 24 to $27^{\circ} 2 \theta$ was conducted to distinguish chlorite from kaolinite by evaluation of the peaks around $25.1^{\circ} 2 \theta$ (Elvelhøi and Rønningsland, 1978). In this study, the background-corrected diagnostic peak intensity was used for evaluating the abundance of each mineral. The relative XRD intensities of quartz at $26.6^{\circ} 2 \theta(d=3.4 \AA)$, feldspar including both plagioclase and $\mathrm{K}$ feldspar at $27.7^{\circ} 2 \theta(d=$ $3.2 \AA)$, illite including mica at $8.8^{\circ} 2 \theta(d=10.1 \AA)$, chlorite including kaolinite (called "chlorite+kaolinite" hereafter $)$ at $12.4^{\circ} 2 \theta(d=7.1 \AA)$, kaolinite at $24.8^{\circ} 2 \theta(d=$ $3.59 \AA)$, chlorite at $25.1^{\circ} 2 \theta(d=3.54 \AA)$, and dolomite at $30.9^{\circ} 2 \theta(d=2.9 \AA)$ were determined using MacDiff software (Petschick, 2000) based on the peak identification protocols of Biscaye (1965).

The mineral ratios used in this study are defined based on XRD peak intensities (PIs) as

$$
\begin{aligned}
& \mathrm{Q} / \mathrm{F}=\text { quartz/feldspar }=\left[\mathrm{PI} \text { at } 26.6^{\circ} 2 \theta\right] /\left[\mathrm{PI} \text { at } 27.7^{\circ} 2 \theta\right] \\
& \begin{aligned}
\mathrm{CK} / \mathrm{I} & =(\text { chlorite }+ \text { kaolinite }) / \text { illite } \\
& =\left[\mathrm{PI} \text { at } 12.4^{\circ} 2 \theta\right] /\left[\mathrm{PI} \text { at } 8.8^{\circ} 2 \theta\right]
\end{aligned} \\
& \mathrm{C} / \mathrm{I}=\text { chlorite } / \text { illite }=\left[\mathrm{PI} \text { at } 25.1^{\circ} 2 \theta\right] /\left[\mathrm{PI} \text { at } 8.8^{\circ} 2 \theta\right] \\
& \mathrm{K} / \mathrm{I}=\text { kaolinite } / \text { illite }=\left[\mathrm{PI} \text { at } 24.8^{\circ} 2 \theta\right] /\left[\mathrm{PI} \text { at } 8.8^{\circ} 2 \theta\right] .
\end{aligned}
$$

The standard error of duplicate analyses in all samples averaged 1.1, 0.08, and 0.05 for Q / F, CK / I, and C / I ratios, respectively.

Clay minerals (less than $2 \mu \mathrm{m}$ diameter) in core 01A-GC were separated by the settling method based on the Stokes law (Müller, 1967). To produce an oriented powder XRD sample, the collected clay suspensions were vacuum-filtered onto $0.45 \mu \mathrm{m}$ nitrocellulose filters and dried. Ethylene glycol $(50 \mu \mathrm{L})$ was then soaked onto the oriented clay on the filters. Glycolated sample filters were stored in an oven at $70^{\circ} \mathrm{C}$ for $4 \mathrm{~h}$ and then immediately subjected to XRD analyses. Each sample filter was placed directly on a glass slide and X-rayed with a tube voltage of $40 \mathrm{kV}$ and current of $20 \mathrm{~mA}$. Scanning speed was $0.5^{\circ} 2 \theta \mathrm{min}^{-1}$ and the data-sampling step was $0.02^{\circ} 2 \theta$ from 2 to $15^{\circ} 2 \theta$. An additional precise scan with a scanning speed of $0.2^{\circ} 2 \theta \mathrm{min}^{-1}$ and sampling step of $0.01^{\circ} 2 \theta$ from 24 to $27^{\circ} 2 \theta$ was conducted to distinguish chlorite from kaolinite by evaluation of the peaks around $25.1^{\circ} 2 \theta$ (Elvelh $\varnothing i$ and Rønningsland, 1978). The standard errors of duplicate analyses in all samples averaged 0.05 and 0.06 for CK / I and C / I ratios, respectively.
The diffraction intensity of chlorite+kaolinite at $7.1 \AA$ was significantly positively correlated with that of chlorite at $3.54 \AA(r=0.89)$ but not with that of kaolinite at $3.59 \AA$ $(r=0.39)$ in western Arctic surface sediments (Kobayashi et al., 2016), indicating that the diffraction intensity of chlorite+kaolinite is governed by the amount of chlorite rather than that of kaolinite.

Spectral analyses of the downcore Q / F and C / I variability were performed using the maximum-entropy method provided in the Analyseries software package (Paillard et al., 1996).

\section{Results}

\subsection{Surface sediments of the Beaufort Sea}

Because the dataset of Kobayashi et al. (2016) has only one sample in the eastern Beaufort Sea, we added the data of 16 samples from the eastern Beaufort Sea near the Mackenzie Delta and 3 samples from the western Beaufort Sea to fill the gaps in their dataset. The new combined dataset shows more clearly than Kobayashi et al. (2016) that the surface sediments in the eastern Beaufort Sea have higher Q / F and lower CK / I and C / I ratios than those in the Chukchi Sea (Fig. 2a-c; Supplement Table S1).

The Q / F ratio showed a westward decreasing trend from the eastern Beaufort Sea to the East Siberian Sea and its offshore area (Fig. 2d). This supports a notion that quartzrich but feldspar-poor sediments are derived from the North American margin by the BG circulation, whereas feldsparrich sediments are delivered to the Chukchi Sea from the Siberian margin by currents along the East Siberian slope (Vogt, 1997; Stein, 2008; Darby et al., 2011; Kobayashi et al., 2016).

The CK / I and C / I ratios showed a northward decreasing trend in the Chukchi Sea and the Chukchi Borderland (Fig. 2e). These results are consistent with earlier studies showing that illite is a common clay mineral in Arctic sediments (Kalinenko, 2001; Darby et al., 2011), whereas chlorite is more abundant in the Bering Sea and the Chukchi shelf areas influenced by the BSI (Naidu and Mowatt, 1983; Kalinenko, 2001; Nwaodua et al., 2014; Kobayashi et al., 2016).

These trends support the conclusion of Kobayashi et al. (2016) mentioning that the Q/F ratio can be used as a provenance index for the $\mathrm{BG}$ circulation reflecting a westward decrease in its intensity, and the CK/I and C / I ratios can be used as a provenance index for the BSI reflecting a northward decrease in its intensity. The provenance and transportation of these detrital minerals are discussed in detail in Naidu and Mowatt (1983), Kalinenko (2001), Nwaodua et al. (2014), and Kobayashi et al. (2016). 


\subsection{Cores 01A-GC, 05JPC/TC, and 06JPC}

Quartz, feldspar, including plagioclase and K feldspar, illite, chlorite, kaolinite, and dolomite were detected in the study samples. Plagioclase comprises a variety of anorthite and albite. Microscopic observations of smear slides for the study samples revealed that quartz and feldspar are the two major minerals in the composition of detrital grains.

The variation patterns of the Q / F, C / I, CK / I, and K / I ratios are different for fine-grained and glaciomarine units in cores 05JPC/TC and 06JPC (Fig. 3; Supplement Tables S3S5). The ratios of the fine-grained unit are relatively stable compared with those in glaciomarine units. The higher $\mathrm{Q} / \mathrm{F}$ ratio in glaciomarine units is consistent with the finding of previous studies that quartz grains are abundant in the western Arctic sediments delivered from the Laurentide ice sheet during glacial and deglacial periods (Bischof et al., 1996; Bischof and Darby, 1997; Phillips and Grantz, 2001; Kobayashi et al., 2016). Some peaks correspond to dolomiterich layers ("D" in Fig. 3). Variation in the K/I ratio was associated with that in the Q/F ratio (Fig. 3), which is in harmony with an idea that kaolinite was delivered via the Beaufort Gyre circulation (Kobayashi et al., 2016). The C / I and $\mathrm{CK} / \mathrm{I}$ ratios are lower in the glaciomarine unit than in the fine-grained unit in 06JPC (Fig. 3c), which is consistent with the closure of the Bering Strait in the last glacial (Elias et al., 1992), but this difference is not significant in 05JPC (Fig. 3b). High-amplitude fluctuations were observed in the $\mathrm{C} / \mathrm{I}$ and $\mathrm{CK} / \mathrm{I}$ ratios in the fine-grained sediments in 01AGC and 06JPC (Fig. 3a and c). Similar fluctuations partly appeared in 05JPC/TC despite its lower sampling resolution (Fig. 3b).

The Q / F ratio in cores 01A-GC, 05JPC/TC, and 06JPC shows a gradual long-term decrease throughout the Holocene (Fig. 4a). In cores 01A-GC and 06JPC studied in more detail, the Q / F ratio also indicates millennial- to century-scale variability (Fig. 4a). Variations in the five-point running average highlight millennial-scale patterns (Fig. 4a). The variations are generally asynchronous between both cores on this timescale, which strongly depends on their age-depth models.

In core 01A-GC, the CK / I and C / I ratios show a general increase after ca. $9.5 \mathrm{ka}$ with the highest values occurring between 6 and $4 \mathrm{ka}$, and high ratios around 2.5 and $1 \mathrm{ka}$ (Fig. 4b). In core 06JPC, the ratios show a general increase after $9.2 \mathrm{ka}$, with higher values occurring between 6 and $3 \mathrm{ka}$ (Fig. 4b). In core 05JPC/TC, slightly higher ratios occur between 6 and $3 \mathrm{ka}$ after a gradual increase from $9.3 \mathrm{ka}$ (Fig. 4b).

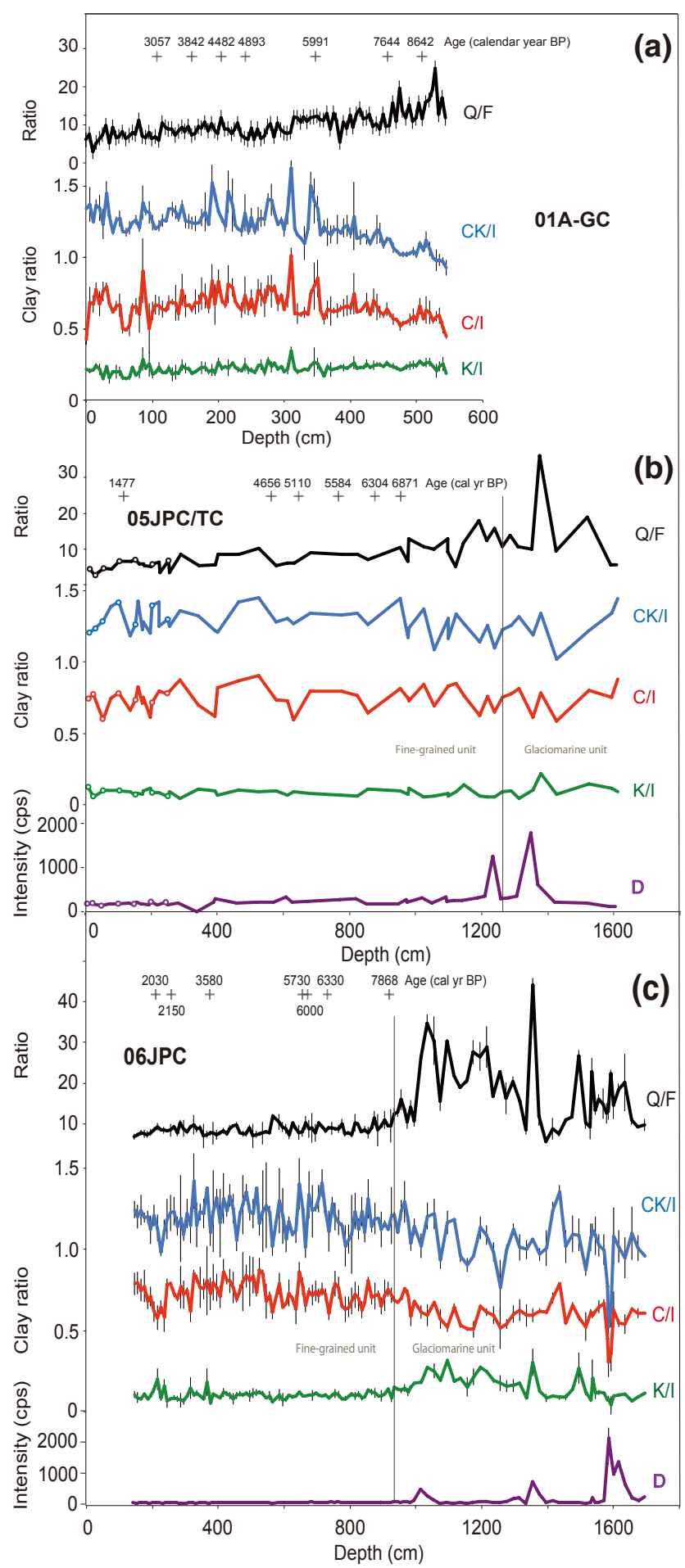

Figure 3. Depth profile in the quartz / feldspar (Q / F) ratio, (chlorite + kaolinite) / illite $(\mathrm{CK} / \mathrm{I})$ and the chlorite / illite $(\mathrm{C} / \mathrm{I})$ and kaolinite / illite $(\mathrm{K} / \mathrm{I})$ ratios with $1 \sigma$ intervals (analytical error) and the diffraction intensity of dolomite (D) in cores (a) ARA02B 01A-GC, (b) HLY0501-05JPC/TC, and (c) HLY0501-06JPC (Supplement Tables S2-S4). Crosses indicate radiocarbon dates in 01GC and 5JPC and paleo-intensity datums in 06JPC. Open circles in panel (b) indicate 05TC samples. Note that the depth scale for 01A-GC is doubled for presentation purposes. 


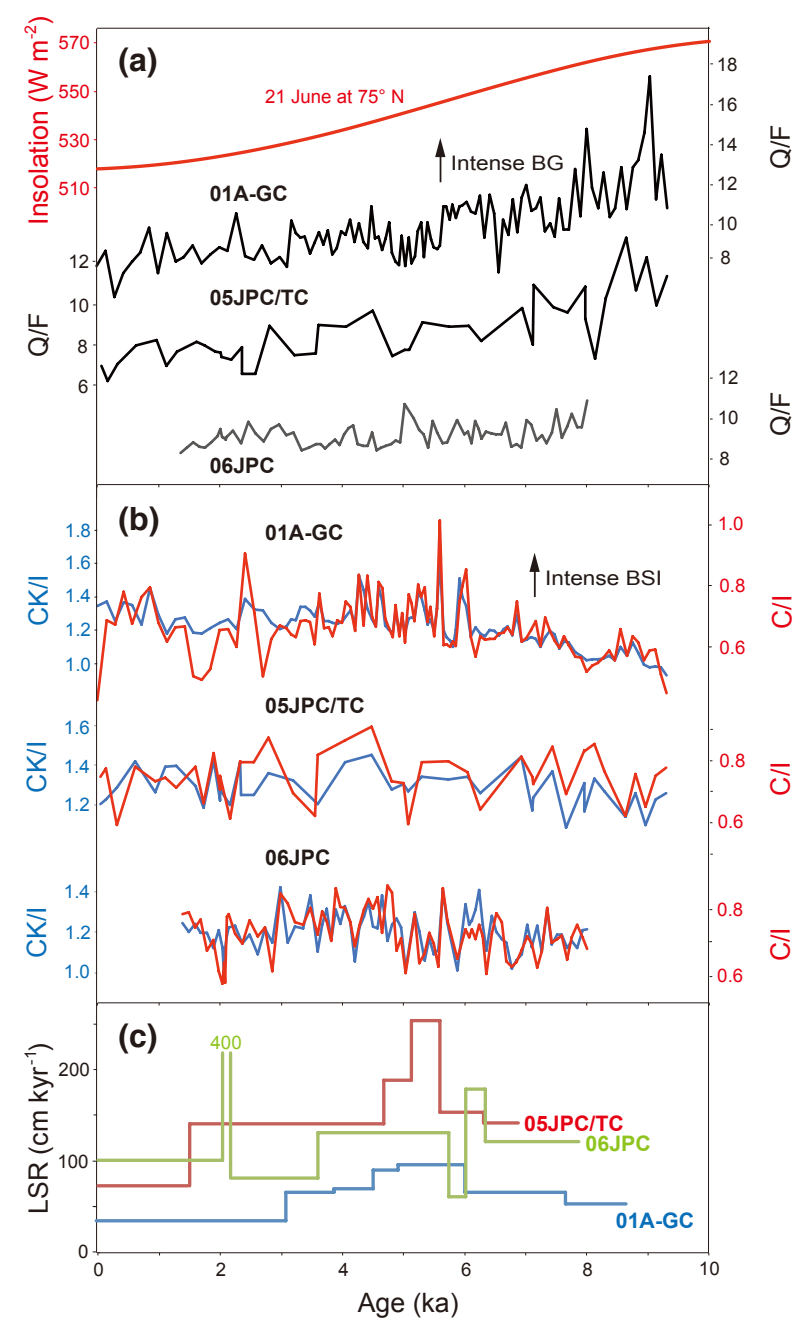

Figure 4. Holocene changes in (a) the quartz / feldspar (Q / F) ratio and the June insolation at $75^{\circ} \mathrm{N},(\mathbf{b})$ (chlorite + kaolinite) / illite $(\mathrm{CK} / \mathrm{I})$ and chlorite / illite $(\mathrm{C} / \mathrm{I})$ ratios, and (c) linear sedimentation rates (LSRs) between age tie points in cores ARA02B 01AGC, HLY0501-05JPC/TC, and HLY0501-06JPC. Note that the age model for 06JPC is very tentative, so that a peak in LSR at ca. $2 \mathrm{ka}$ could be an artifact of spurious age controls.

\section{Discussion}

\subsection{Holocene trend in the Beaufort Gyre circulation}

The zonal gradient of the Q / F ratio in western Arctic sediments shown in Fig. 2 suggests that quartz-rich but feldsparpoor sediments are derived from the North American margin by the BG circulation, whereas feldspar-rich sediments are delivered to the Chukchi Sea from the Siberian margin by currents along the East Siberian slope, and the ratio can be used as an index for the BG circulation reflecting changes in its intensity in sediment-core records (Kobayashi et al., 2016). A consistent decrease in the $Q / F$ ratio in the three different cores under study (Fig. 4a) suggests that the
BG weakened during the Holocene. This pattern is consistent with an orbitally forced decrease in summer insolation at northern high latitudes from the early Holocene to the present. High summer insolation likely melted sea ice in the Canada Basin, in particular in the coastal areas (Fig. 5). The evidence of lower ice concentrations at the Canada Basin margins in the early Holocene has been shown in the fossil records of bowhead whale bones from the Beaufort Sea coast (Dyke and Savelle, 2001) and driftwood from northern Greenland (Funder et al., 2011). This condition could decrease the stability of the ice cover at the margins of the Canada Basin, which accelerated the rotation of the BG circulation (Fig. 5) by comparison with observations from recent decades (Shimada et al., 2006). A decrease in summer insolation during the Holocene should have increased the stability of sea-ice cover along the coasts, resulting in the weakening of the BG.

Recent observations show that the BG circulation is linked to the AO (Proshutinsky and Johnson, 1997; Rigor et al., 2002). In the negative phase of the AO, the Beaufort High strengthens and intensifies the BG. If the gradual weakening of the BG during the Holocene were attributed to atmospheric circulation only, a concurrent shift in the mean state of the AO from the negative to positive phase would be expected. This view, however, contradicts the existing reconstructions of the AO history showing multiple shifts between the positive and negative phases during the Holocene (e.g., Rimbu et al., 2003; Olsen et al., 2012). We thus infer that the decreasing Holocene trend of the BG circulation is attributed not to changes in the AO pattern but rather to the increasing stability of the sea-ice cover in the Canada Basin.

Based on a Holocene sediment record off the northeastern Chukchi margin, Darby et al. (2012) suggested strong positive AO-like conditions between 3 and $1.2 \mathrm{ka}$ based on abundant ice-rafted iron oxide grains from the West Siberian shelf. In contrast, a mostly negative AO in the late Holocene can be inferred from mineralogical proxy data indicating a general decline in the BSI after $4 \mathrm{ka}$ (Ortiz et al., 2009), which could be attributed to a stronger Aleutian Low (Danielson et al., 2014) that typically corresponds to the negative AO (Overland et al., 1999). Olsen et al. (2012) also concluded that the AO tended to be mostly negative from 4.2 to $2.0 \mathrm{ka}$ based on a redox proxy record from a Greenland lake. In order to comprehend these patterns, we need to consider not only the atmospheric circulation but also sea-ice conditions. Based on the Q / F record in this study, summer Arctic sea-ice cover shrank in the early to middle Holocene, so that fast ice containing West Siberian grains could less effectively reach the Canada Basin because sea ice would have melted on the way to the BG (Fig. 5). Later in the Holocene the ice cover expanded, and West Siberian fast ice could survive and be incorporated into the BG (Fig. 5). We infer, therefore, that sediment transportation in the $\mathrm{BG}$ is principally governed by the distribution of summer sea ice and the resultant stability of the ice cover in the Canada Basin. 

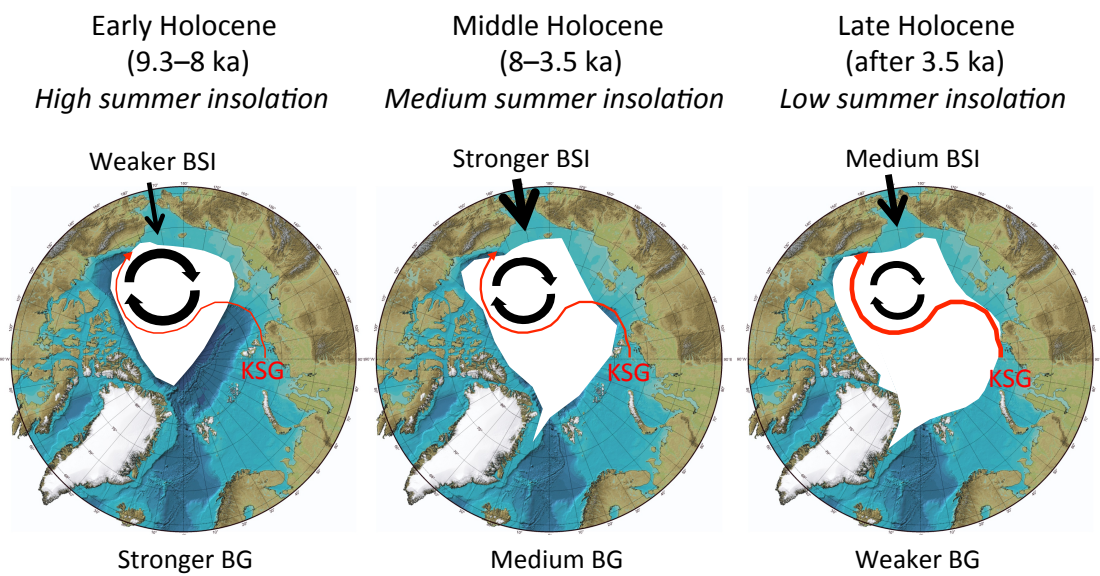

Figure 5. Conceptual map showing the distribution of summer sea ice and the rotation of the Beaufort Gyre (BG) in the early, middle, and late Holocene, inferred from the quartz / feldspar (Q / F) proxy record. Also shown is the Bering Strait inflow (BSI) intensity inferred from the (chlorite + kaolinite) / illite and chlorite / illite ratios. Red arrow indicates the drift path of Kara Sea grains (KSGs; Darby et al., 2012).

\subsection{Millennial variability in the BG circulation}

In addition to the decreasing long-term trend, the $\mathrm{Q} / \mathrm{F}$ ratio in 01A-GC and 06JPC clearly displays millennial- to century-scale variability (Fig. 4a). Variation in the Q/F ratio of both 01A-GC and 06JPC indicates a significant periodicity of $\sim 2100$ and $\sim 1000$ years with weak periodicities of $\sim 500$ and $\sim 360$ years, consistent with prominent periodicities in the variation in total solar irradiance (Fig. 6) (Steinhilber et al., 2009). A comparison with the record of total solar irradiance (Steinhilber et al., 2009) shows a general correspondence, where stronger BG circulation (higher Q / F ratio) corresponds to higher solar irradiance (Fig. 7). A 200-year phase lag between the solar irradiance and the $\mathrm{Q} / \mathrm{F}$ ratio in 01A-GC and 06JPC may be attributed to the underestimation of the local carbon reservoir effect. This pattern suggests that millennial-scale variability in the BG was principally forced by changes in solar irradiance as the most likely forcing. Proxy records consistent with solar forcing were reported from a number of paleoclimatic archives, such as Chinese stalagmites (Hu et al., 2008), Yukon lake sediments (Anderson et al., 2005), and ice cores (Fisher et al., 2008), as well as marine sediments in the northwestern Pacific (Sagawa et al., 2014) and the Chukchi Sea (Stein et al., 2017). Because solar forcing is energetically much smaller than changes in the summer insolation caused by orbital forcing, we suppose that solar activity did not directly affect the stability of ice cover in the Canada Basin. Alternatively, we suggest that the solar activity signal was amplified by positive feedback mechanisms, possibly through changes in the stability of sea-ice cover and/or the atmospheric circulation in the northern high latitudes.

In addition to cycles consistent with the solar forcing, Darby et al. (2012) reported a 1550-year cycle in the Siberian grain variation in the Chukchi Sea record. This cycle was,

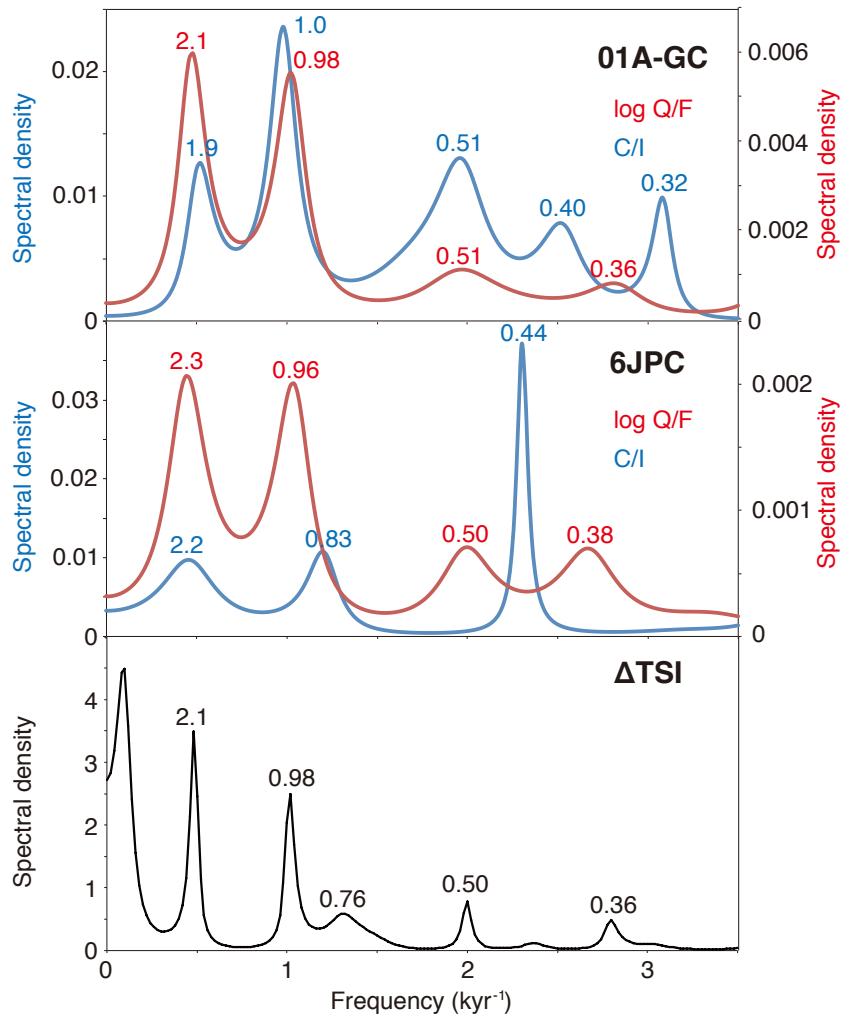

Figure 6. Maximum-entropy power spectra of variation in the quartz / feldspar $(\mathrm{Q} / \mathrm{F})$ and chlorite / illite $(\mathrm{C} / \mathrm{I})$ ratios in core ARA02B 01A-GC $(N=85, m=21)$ and HYL0501-06JPC $(N=$ $79, m=22)$ during $1.4-7.9 \mathrm{ka}$ and the total solar irradiance $(N=$ $932, m=140$ ) (Steinhilber et al., 2009) during the last $9.3 \mathrm{kyr}$. 


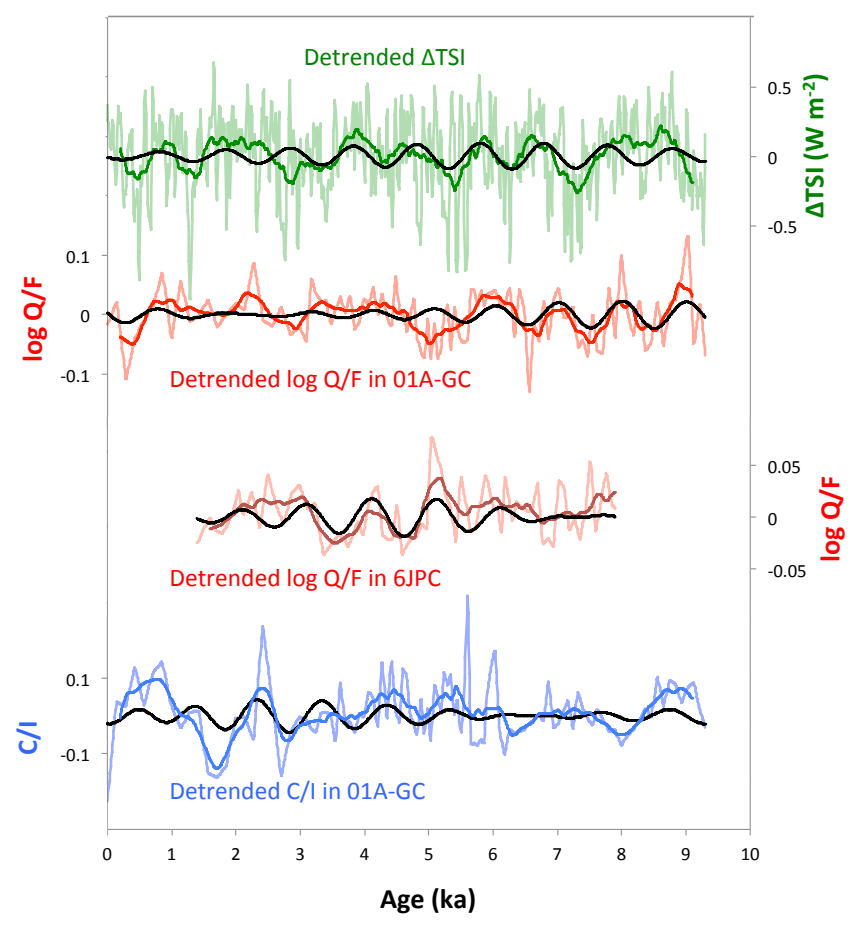

Figure 7. Detrended variations in the solar irradiance (TSI; Steinhilber et al., 2009), the quartz / feldspar (Q / F) ratio in logarithmic scale in cores ARA02B 01A-GC and HYL0501-06JPC, and the chlorite / illite $(\mathrm{C} / \mathrm{I})$ ratio in core ARA02B 01A-GC during the Holocene, with 400-year moving averages and 1000-year filtered variations indicated by dark colored and black lines, respectively. The detrended values were obtained by cubic polynomial regression.

however, not detected in our data, indicative of the BG variation (Fig. 6). This difference suggests that the occurrence of Siberian grains in the Chukchi Sea sediments primarily reflects the formation and transportation of fast ice in the eastern Arctic Ocean rather than changes in the BG circulation.

\subsection{Holocene changes in the Bering Strait inflow}

Northward decreasing trends in the CK / I and C / I ratios in surface sediments in the Chukchi Sea suggests that chloriterich sediments are derived from the northern Bering Sea via the Bering Strait, and the ratios can be used as an index for the BSI reflecting changes in its intensity in sedimentcore records (Kobayashi et al., 2016). Although the variations in the $\mathrm{CK} / \mathrm{I}$ and $\mathrm{C} / \mathrm{I}$ ratios are not identical among the three study cores (Fig. 4b), there is a common long-term trend showing a gradual increase from 9 to $4.5 \mathrm{ka}$ and a decrease afterwards (Fig. 4b). Large fluctuations are significant in $01 \mathrm{~A}-\mathrm{GC}$ from 6 to $4 \mathrm{ka}$, and this fluctuation is also seen in 6JPC to some extent (Fig. 4b).

The higher CK / I and C / I ratios in core 01A-GC in the middle Holocene correspond to higher linear sedimentation rates estimated by interpolation between ${ }^{14} \mathrm{C}$ dating points, but this correspondence is not seen in cores 05JPC/TC and 06JPC (Fig. 4c). We assume that these higher sedimentation rates at $01 \mathrm{~A}-\mathrm{GC}$ indicate intensified BSI because fine sediment in the study area is mostly transported by currents from the Bering Sea and shallow southern Chukchi shelf (Kalinenko, 2001; Darby et al., 2009; Kobayashi et al., 2016). The difference in chlorite and sedimentation rate records between 01A-GC and 05JPC/06JPC may be related to either (1) variable sediment focusing at different water depths or (2) redistribution of the BSI water between different branches after passing the Bering Strait. (1) A sediment-trap study demonstrated that shelf-break eddies in winter are important to carry fine-grained lithogenic material from the Chukchi shelf to the slope areas (Watanabe et al., 2014). This redeposition process may have weakened the BSI signal in slope sediments of 05JPC/06JPC compared with outer-shelf sediments of 01A-GC. (2) Both the ACC and the central current can transport sediment particles to the 05JPC/TC and 06JPC area (red and yellow arrows, respectively, in Fig. 1; Winsor and Chapman, 2004; Weingartner et al., 2005). In comparison, the western branch is more likely to carry sediment particles to the site of 01A-GC (blue arrow in Fig. 1). The redistribution of the BSI water may have caused a different response in BSI signals. Although it is not clear which process made the difference to BSI signals between 01A-GC and 05JPC/06JPC cores, it is highly possible that the sedimentation rate and mineral composition of $01 \mathrm{~A}-\mathrm{GC}$ are more sensitive to changes in BSI intensity than those of the other two sites.

Diffuse spectral reflectance in core HLY0501-06JPC indicated that chlorite + muscovite content is especially high in the middle Holocene between ca. 4 and $6 \mathrm{ka}$ (Supplement Fig. S1; Ortiz et al., 2009). However, this pattern was not confirmed by our XRD analysis, where XRD intensities of chlorite and muscovite (detected as illite in this study) as well as the $\mathrm{C} / \mathrm{I}$ and $\mathrm{CK} / \mathrm{I}$ ratios did not show an identifiable enrichment between 4 and 6 ka (Supplement Fig. S1). We need more research to understand the discrepancy between the results.

\subsection{Millennial variability in the BSI}

Variation in the $\mathrm{C} / \mathrm{I}$ ratio of $01 \mathrm{~A}-\mathrm{GC}$ indicates a significant periodicity of 1900, 1000, 510, 400 and 320 years (Fig. 6a). The 1900-, 1000-, and 510-year periodicities are consistent with prominent periodicities in the variation in total solar irradiance (Fig. 6c) (Steinhilber et al., 2009). On the other hand, variation in the C / I ratio of 06JPC indicates a periodicity of 2200, 830, and 440 years (Fig. 6b). The periodicity is different from that in 01A-GC (Fig. 6a). This suggests that there are different agents of BSI signals in cores 01A-GC and 06JPC. In core 01A-GC, 1000-year filtered variation in the $\mathrm{C}$ / I ratio is nearly antiphase with those of the Q / F ratio and total solar irradiance (Steinhilber et al., 2009) between 0 and $5 \mathrm{ka}$ (Fig. 7). This suggests that millennial-scale variabil- 
ity in the western branch of the BSI was forced by changes in solar irradiance after $5 \mathrm{ka}$. Recent observations demonstrated that the BSI flows northwestward, especially when easterly winds prevent the ACC (Winsor and Chapman, 2004). Because the easterly winds drive the BG circulation, this mechanism cannot explain the increase in BSI intensity when the BG weakened. Alternatively, it is also possible that the solar forcing could independently regulate the western branch of the BSI via unknown atmospheric-oceanic dynamics.

\subsection{Ocean circulation, sea ice, and biological production}

The BSI, an important carrier of heat to the Arctic, affects sea-ice extent in the Chukchi Sea (e.g., Shimada et al., 2006). Sea-ice concentrations in the Chukchi Sea during the Holocene were reconstructed by dinoflagellate cysts (de Vernal et al., 2005, 2008, 2013; Farmer et al., 2011) and biomarker $\mathrm{IP}_{25}$ (Polyak et al., 2016; Stein et al., 2017).

In central northern Chukchi Sea, $\mathrm{IP}_{25}$ records showed that the sea-ice concentration indicated by the $\mathrm{PIP}_{25}$ index in core 01A-GC was lower in 9-7.5 and 5.5-4 ka (Fig. 8a; Stein et al., 2017), suggesting less sea-ice conditions in the periods. The low sea-ice concentration during 9-7.5 ka is consistent with the results of previous studies based on dinoflagellate cyst and $\mathrm{IP}_{25}$ records showing the widespread sea-ice retreat in the Arctic Ocean, which was attributed to higher summer insolation during the early Holocene (Dyke and Savelle, 2001; Vare et al., 2009; de Vernal et al., 2013; Stein et al., 2017). On the other hand, the sea-ice retreat during $5.5-4 \mathrm{ka}$ cannot be explained by higher summer insolation. This period corresponds to that of higher $\mathrm{C} / \mathrm{I}$ and $\mathrm{CK} / \mathrm{I}$ ratios indicative of the stronger BSI at 01A-GC (Fig. 8a). This suggests that the strengthened BSI during this period contributed to sea-ice retreat in the central Chukchi Sea.

In the northeastern Chukchi Sea, dinoflagellate cyst and biomarker $\mathrm{IP}_{25}$ records from several cores in the northeastern Chukchi Sea, including 05JPC, demonstrate that sea-ice concentration in this area was overall higher in the early Holocene than in the middle and late Holocene (Fig. 8; de Vernal et al., 2005, 2008, 2013; Farmer et al., 2011; Polyak et al., 2016). This pattern contrasts with reconstructions from other Arctic regions that show lower sea-ice concentrations in the early Holocene (de Vernal et al., 2013). This discrepancy suggests that the intensified BG circulation exported more ice from the Beaufort Sea to the northeastern Chukchi Sea margin. Furthermore, the heat transport from the North Pacific to the Arctic Ocean by the BSI was likely weaker in the early Holocene than at later times as indicated by the C / I and CK / I ratios of cores 06JPC and 01A-GC (Fig. 8). We infer that this combination of stronger BG circulation and weaker BSI in the early Holocene resulted in increased sea-ice concentration in the northeastern Chukchi Sea despite high insolation levels (Fig. 5). In comparison, intense BSI, a crucial agent of heat transport from the North Pacific to the Arctic Ocean, along with a weaker BG in the middle

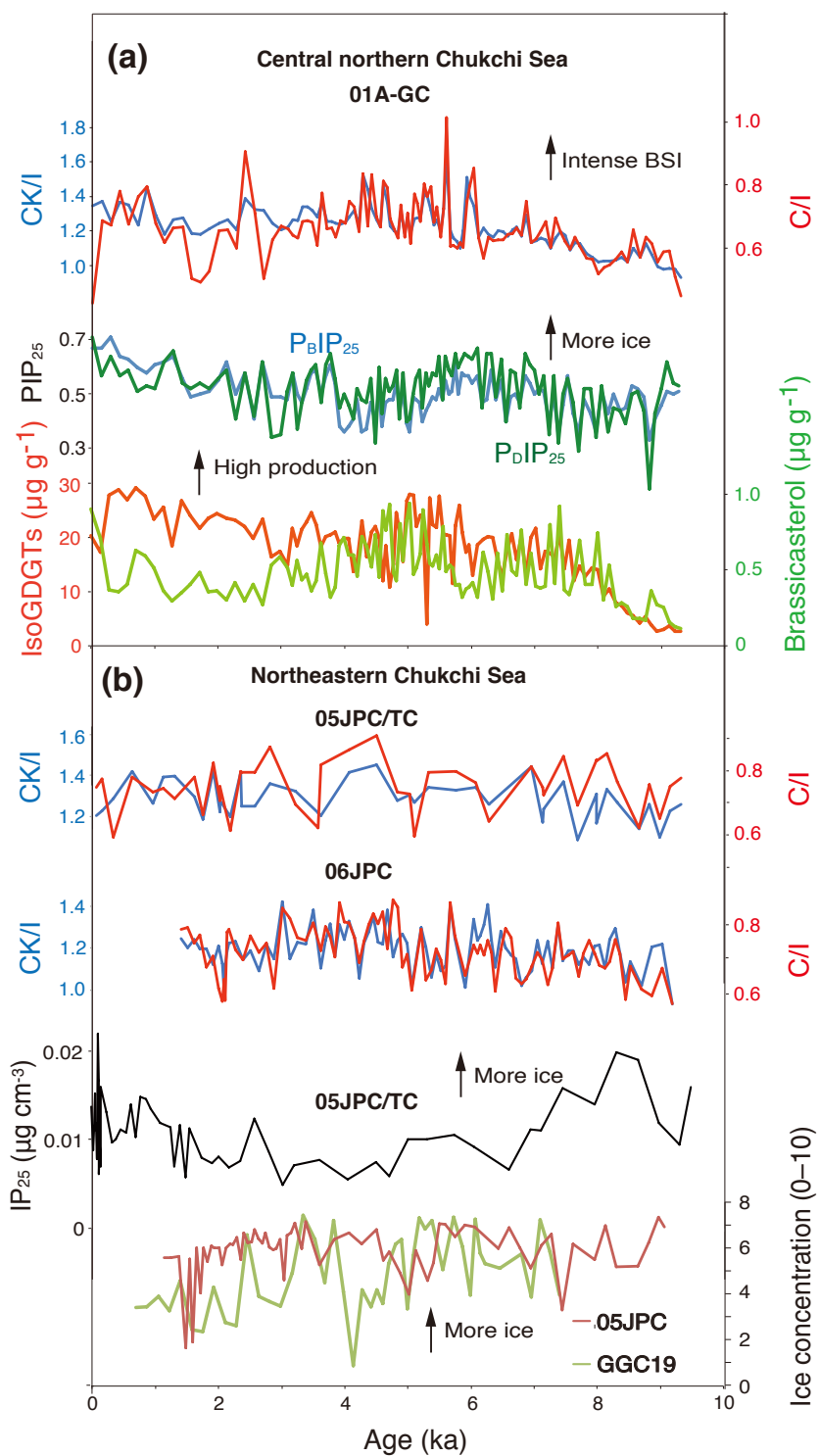

Figure 8. Changes in (a) (chlorite + kaolinite) / illite (CK / I) and chlorite / illite $(\mathrm{C} / \mathrm{I})$ ratios, $\mathrm{PIP}_{25}\left(\mathrm{P}_{\mathrm{D}} \mathrm{IP}_{25}\right.$ and $\mathrm{P}_{\mathrm{B}} \mathrm{IP}_{25}$ based on $\mathrm{IP}_{25}$ and dinosterol or brassicasterol concentrations) indices (Stein et al., 2017), and isoprenoid GDGT (Park et al., 2016) and brassicasterol concentrations (Stein et al., 2017) in core ARA02B 01AGC; (b) CK / I and C / I ratios in core HLY0510-5JPC/TC, IP 25 concentrations in core HLY0510-5JPC (Polyak et al., 2016), and mean annual sea ice cover concentration (scale from 0 to 10) estimated from dinoflagellate cyst assemblages in cores 05JPC and GGC19 (de Vernal et al., 2013).

Holocene likely reduced sea-ice cover in the Chukchi Sea. During the late Holocene, characterized by the weakest BG and moderate BSI, sea-ice concentrations were intermediate and strongly variable (Fig. 8; de Vernal et al., 2008, 2013; Polyak et al., 2016).

The nutrient supply by the BSI potentially affects marine production in the Chukchi Sea. We tested this possibility to 
compare our BSI record with marine production records from cores 01A-GC (Park et al., 2016; Stein et al., 2017). Isoprenoid glycerol dialkyl glycerol tetraethers (GDGTs) and brassicasterol showed concentration maxima during the periods between 8 and $7.5 \mathrm{ka}$ and 6 and $4.5 \mathrm{ka}$ (Fig. 8a). Isoprenoid GDGTs are produced by marine Archaea (Nishihara et al., 1987) that use ammonia, urea, and organic matter in the water column (Qin et al., 2014). Brassicasterol is known as a sterol which is abundant in diatoms (Volkman, 1986). Their abundance can, thus, be used as proxies to indicate marine production in the water column. The periods with abundant isoprenoid GDGTs and brassicasterol corresponded to the periods of low PIP $_{25}$ indicative of less sea ice (Fig. 8a). This correspondence suggests that the biological productivity increased with the retreat of sea ice in the Chukchi Sea during the middle Holocene. The BSI indices, the $\mathrm{C} / \mathrm{I}$ and CK / I ratios, showed a maximum between 6 and $4 \mathrm{ka}$, which corresponded to the periods of high marine production, but the corresponding maximum between 8 and $6.5 \mathrm{ka}$ is not significant. Also, correspondence between the BSI indices and biomarker concentrations are not clear after $4 \mathrm{ka}$. This suggests that marine production was not a simple response to nutrient supply but was affected by other processes such as the increase in irradiance in the water column (Frey et al., 2011; Lee and Whitledge, 2005) and wind-induced mixing that replenishes sea surface nutrients (Carmack et al., 2006).

\subsection{Causes of BSI variations}

Chukchi Sea sedimentary core records indicate a considerable variability in the BSI intensity, with a common longterm trend of a gradual increase from 9 to $4.5 \mathrm{ka}$ and a decrease afterwards (Fig. 4b). Below we discuss the possible controls on this variability.

The timing of the initial postglacial flooding of the $\sim 50 \mathrm{~m}$ deep Bering Strait was estimated as between ca. 12 and $11 \mathrm{ka}$ (Elias et al., 1992; Keigwin et al., 2006; Jakobsson et al., 2017). The gradual intensification of the BSI inferred from the increase in chlorite content from ca. 9 to $6 \mathrm{ka}$ may have been largely controlled by the widening and deepening of the Bering Strait with rising sea level, although other factors as discussed below still need to be tested. After the sea level rose to nearly the present position by ca. $6 \mathrm{ka}$, its influence on changes in the BSI volume was negligible.

The possible driving forces of the BSI at full interglacial sea level may include several controls. One is related to the sea surface height difference between the Pacific and Atlantic oceans regulated by the atmospheric moisture transport from the Atlantic to the Pacific Ocean across Central America (Stigebrandt, 1984). An increase in this moisture transport during warm climatic intervals (Leduc et al., 2007; Richter and Xie, 2010; Singh et al., 2016) may have intensified the BSI. Salinity proxy data for the last $90 \mathrm{kyr}$ from the equatorial east Pacific confirm increased precipitation during warm events but also show the moisture transport across Central
America may operate efficiently only during intervals with a northerly position of the Intertropical Convergence Zone due to orographic constraints (Leduc et al., 2007). The existing Holocene salinity records from the North Pacific (e.g., Sarnthein et al., 2004) do not yet provide sufficient material to test the impact of these changes on the BSI.

The interplay of the global wind field and the Atlantic meridional overturning circulation has been proposed as another potential control on the BSI (De Boer and Nof, 2004; Ortiz et al., 2012). Results of an analytical ocean modeling experiment (Sandal and Nof, 2008) based on the island rule (Godfrey, 1989) suggest that weaker subantarctic westerlies in the middle Holocene could decrease the near-surface, cross-equatorial flow from the Southern Ocean to the North Atlantic, thus enhancing the BSI and Arctic outflow into the Atlantic. This hypothesis awaits more thorough testing, including by robust proxy records of the subantarctic westerlies over the Southern Ocean.

Finally, BSI can be controlled by the regional wind patterns in the Bering Sea (Danielson et al., 2014), as explained above in Sect. 2.1. Oceanographic observations of 20002011 clearly show a decadal response of the BSI to a change in the sea level pressure in the Aleutian Basin affecting the dynamic sea surface height along the Bering Strait pressure gradient. In order to draw conclusions on whether this relationship holds on longer timescales, longer-term records are needed from areas affected by the BSI and the Bering Sea pressure system.

A number of proxy records from the Bering Sea and adjacent regions, both marine and terrestrial, have been used to characterize paleoclimatic conditions related to changes in the Bering Sea pressure system (e.g., Barron et al., 2003; Anderson et al., 2005; Katsuki et al., 2009; Barron and Anderson, 2011; Osterberg et al., 2014). Various proxies used in these records consistently show that the Aleutian Low was overall weaker in the middle Holocene than in the late Holocene, the opposite of the BSI strength inferred from our Chukchi Sea data (Fig. 4b). For example, multi-proxy data from the interior of Alaska and adjacent territories (Kaufman et al., 2016, and references therein) indicate overall drier and warmer conditions in the middle Holocene, consistent with a weaker Aleutian Low and stronger BSI. Diatom records from the southern Bering Sea indicate more abundant sea ice in the middle Holocene, also suggestive of a weaker Aleutian Low (Katsuki et al., 2009). Alkenone and diatom records from the California margin show that the sea surface temperature was lower in the middle Holocene, suggesting stronger northerly winds indicative of a weaker Aleutian Low (Barron et al., 2003). The intensification of the Aleutian Low in the late Holocene, which follows from these results, would have decreased sea level pressure in the Aleutian Basin, and thus the strength of the BSI, consistent with overall lower BSI after ca. 4 ka inferred from the Chukchi Sea sedimentcore data (Fig. 4). The considerable climate variability in the Bering Sea region captured in the upper Holocene records, 
Table 1. Summary of Holocene variability in the BG and BSI in the northern Chukchi Sea.

\begin{tabular}{lll}
\hline Current system & Holocene trends & Multi-centennial to millennial cyclicity \\
\hline $\begin{array}{l}\text { Beaufort Gyre } \\
\text { circulation }\end{array}$ & $\begin{array}{l}\text { Gradual weakening in response to decreas- } \\
\text { ing summer insolation. }\end{array}$ & $\begin{array}{l}0.36,0.5,1, \text { and 2 ky cycles paced by } \\
\text { changes in solar activity. }\end{array}$ \\
\hline Bering Strait inflow & $\begin{array}{l}\text { Geographically variable. Mid-Holocene } \\
\text { strengthening evident at the 01A-GC site, } \\
\text { presumably due to weaker Aleutian Low. }\end{array}$ & $\begin{array}{l}\text { Geographically variable; } \sim 0.36,0.5,1, \\
\text { and 2 kyr cycles paced by changes in so- } \\
\text { lar activity are identifiable in 01A-GC. }\end{array}$ \\
\hline
\end{tabular}

some of which have a very high temporal resolution, is also closely linked to the pressure system changes (Anderson et al., 2005; Porter, 2013; Osterberg et al., 2014; Steinman et al., 2014). In particular, the weakening of the Aleutian Low is reflected in Alaskan ice (Porter, 2013; Osterberg et al., 2014) and lake cores (Anderson et al., 2005; Steinman et al., 2014) at intervals centered around ca. 2 and $1-0.5 \mathrm{ka}$, which may correspond to BSI increases in the Chukchi core 01A-GC at ca. 2.5 and $1 \mathrm{ka}$ (Fig. 4), considering the uncertainties of the sparse age constraints in the upper Holocene and/or underestimation of reservoir ages. Overall, the Aleutian Low control on the BSI on century to millennial timescales is corroborated by ample proxy data in comparison with the other potential controls, although more evidence is still required for a comprehensive interpretation.

\section{Summary and conclusions}

The distribution of minerals in surficial bottom sediments from the Chukchi Sea shows two distinct trends: an eastwest gradient in quartz / feldspar ratios along the shelf margin and a northwards decrease in the chlorite contents. These trends are consistent with the propagation of the Beaufort Gyre circulation in the western Arctic Ocean and the Bering Strait inflow to the Chukchi Sea, respectively. The application of these lithological proxies to sedimentary records from the north-central and northeastern parts of the Chukchi Sea allows for an identification of the Holocene paleooceanographic patterns with century to millennial resolution. Results of the identified Holocene changes in the BG circulation and the BSI are summarized in Table 1.

The inferred BG weakening during the Holocene, likely driven by the orbitally controlled summer insolation decrease, indicates basin-wide changes in the Arctic current system and suggests that the stability of sea ice is a key factor regulating the Arctic Ocean circulation on the long-term (e.g., millennial) timescales. This conclusion helps to better understand a dramatic change in the BG circulation during the last decade, probably caused by sea-ice retreat along the margin of the Canada Basin and a more efficient transfer of the wind momentum to the ice and underlying waters (Shimada et al., 2006). These results suggest that the rotation of the BG is likely to be further accelerated by the projected future retreat of summer Arctic sea ice.
The identified millennial to multi-centennial variability in the BG circulation (quartz / feldspar ratio) is consistent with Holocene fluctuations in solar irradiance, suggesting that solar activity affected the BG strength on these timescales.

Changes in the BSI inferred from the proxy records show a considerable variability between the investigated sediment cores, likely related to interactions of different current branches and depositional processes. Overall, we conclude that after the establishment of the full interglacial sea level in the early Holocene, the BSI variability was largely controlled by the Bering Sea pressure system (strength and position of the Aleutian Low). Details of this mechanism, as well as contributions from other potential BSI controls, such as climatically driven Atlantic-Pacific moisture transfer and the impact of global wind stress, need to be further investigated. A consistent intensification of the BSI identified in the middle Holocene was associated with a decrease in seaice extent and an increase in marine production, indicating a major influence of the BSI on sea ice and biological activity in the Chukchi Sea. In addition, multi-century to millennial fluctuations, presumably controlled by solar activity, are discernible in core $01 \mathrm{~A}-\mathrm{GC}$, which is characterized by the highest age resolution.

Data availability. All data are shown in the Supplement.

\section{The Supplement related to this article is available online at https://doi.org/10.5194/cp-13-1111-2017-supplement.}

Competing interests. The authors declare that they have no conflict of interest.

Special issue statement. This article is part of the special issue "Climate-carbon-cryosphere interactions in the East Siberian Arctic Ocean: past, present and future (TC/BG/CP/OS inter-journal SI)". It is not associated with a conference.

Acknowledgements. We thank the captain, crew, and scientists of RV Araon for their help during the sampling cruise. We 
also thank Yu-Hyeon Park, Anne de Vernal, Seth L. Danielson, Julie Brigham-Grette, and Kaustubh Thirumalai for valuable discussion; So-Young Kim, Hyo-Sun Ji, Yeong-Ju Son, Duk-Ki Han, and Hyoung-Jun Kim for assistance in coring and subsampling; and Keiko Ohnishi for analytical assistance. Comments by Martin Jakobsson, Tomas M. Cronin, and an anonymous reviewer greatly improved this paper. The study was supported by a Grantin-Aid for Scientific Research (B) from the Japan Society for the Promotion of Science, No. 25287136 (to Masanobu Yamamoto), a Basic Research Project (PE16062) of the Korean Polar Research Institute, and the NRF of Korea Grant funded by the Korean Government (NRF-2015M1A5A1037243) (to Seung-Il Nam).

Edited by: Martin Jakobsson

Reviewed by: Thomas M. Cronin and one anonymous referee

\section{References}

Aagaard, K., Weingartner, T. J., Danielson, S. L., Woodgate, R. A., Johnson, G. C., and Whitledge, T. E.: Some controls on flow and salinity in Bering Strait, Geophys. Res. Lett., 33, L19602, https://doi.org/10.1029/2006GL026612, 2006.

Anderson, L., Abbott, M. B., Finney, B. P., and Burns, S. J.: Regional atmospheric circulation change in the North Pacific during the Holocene inferred from lacustrine carbonate oxygen isotopes, Yukon Territory, Canada, Quaternary Res., 64, 21-35, 2005.

Barletta, F., St-Onge, G., Channell, J. E. T., Rochon, A., Polyak, L., and Darby, D.: High resolution paleomagnetic secular variation and relative paleointensity records from the western Canadian Arctic: implication for Holocene stratigraphy and geomagnetic field behaviour, Can. J. Earth Sci., 45, 1265-1281, 2008.

Barron, J. A. and Anderson, L.: Enhanced Late Holocene ENSO/PDO expression along the margins of the eastern North Pacific, Quatern. Int., 235, 3-12, 2011.

Barron, J. A., Heusser, L., Herbert, T., and Lyle, M.: Highresolution climatic evolution of coastal northern California during the past 16,000 years, Paleoceanography, 18, 1020, https://doi.org/10.1029/2002PA000768, 2003.

Biscaye, P.: Mineralogy and sedimentation of recent deep-sea clay in the Atlantic Ocean and adjacent seas and oceans, Geol. Soc. Am. Bull., 76, 803-832, 1965.

Bischof, J. and Darby, D. A.: Mid- to Late Pleistocene ice drift in the western Arctic Ocean: Evidence for a different circulation in the Past, Science, 277, 74-78, 1997.

Bischof, J., Clark, D. L., and Vincent, J. S.: Origin of ice rafted debris: Pleistocene paleoceanography in the western Arctic Ocean, Paleoceanography, 11, 743-756, 1996.

Carmack, E., Barber, D., Christensen, J., Macdonald, R., Rudels, B., and Sakshaug, E.: Climate variability and physical forcing of the food webs and the carbon budget on pan-Arctic shelves, Prog. Oceanogr., 71, 145-181, 2006.

Coachman, L. K. and Aagaard, K.: On the water exchange through Bering Strait, Limnol. Oceanogr., 11, 44-59, 1966.

Danielson, S. L., Weingartner, T. J., Hedstrom, K. S., Aargaard, K., Woodgate, R., Curchister, E., and Stabeno, P. J.: Coupled wind-forced controls of the Bering-Chukchi shelf circulation and the Bering Strait throughflow: Ekman transport, continental shelf waves, and variations of the Pacific-Arctic sea surface height gradient, Prog. Oceanogr., 125, 40-61, 2014.
Darby, D. A., Ortiz, J. D., Polyak, L., Lund, S., Jakobsson, M., and Woodgate, R. A.: The role of currents and sea ice in both slowly deposited central Arctic and rapidly deposited Chukchi-Alaskan margin sediments, Global Planet. Change, 68, 58-72, 2009.

Darby, D. A., Myers, W. B., Jakobsson, M., and Rigor, I.: Modern dirty sea ice characteristic and sources: The role of anchor ice, J. Geophys. Res., 116, C09008, https://doi.org/10.1029/2010JC006675, 2011.

Darby, D. A., Ortiz, J. D., Grosch, C. E., and Lund, S. P.: 1,500year cycle in the Arctic Oscillation identified in Holocene Arctic sea-ice drift, Nat. Geosci., 5, 897-900, 2012.

De Boer, A. M. and Nof, D.: The exhaust valve of the North Atlantic, J. Climate, 17, 417-422, 2004.

de Vernal, A., Hillaire-Marcel, C., and Darby, D. A.: Variability of sea ice cover in the Chukchi Sea (western Arctic Ocean) during the Holocene, Paleoceanography, 20, PA4018, https://doi.org/10.1029/2005PA001157, 2005.

de Vernal, A., Hillaire-Marcel, C., Solignac, S., Radi, T., and Rochon, A.: Reconstructing sea ice conditions in the Arctic and sub-Arctic prior to human observations, Geophysical Monograph 180, American Geophysical Union, Washington, USA, 27-45, 2008.

de Vernal, A., Hillaire-Marcel, C., Rochon, A., Fréchette, B., Henry, M., Solignac, S., and Bonnet, S. : Dinocyst-based reconstructions of sea ice cover concentration during the Holocene in the Arctic Ocean, the northern North Atlantic Ocean and its adjacent seas, Quaternary Sci. Rev., 79, 111-121, 2013.

Dyke, A. S. and Savelle, J. M.: Holocene history of the Bering Sea bowhead whale (Balaena mysticetus) in Its Beaufort Sea summer grounds off southwestern Victoria Island, western Canadian Arctic, Quaternary Res., 55, 371-379, 2001.

Elias, S., Short, S. K., and Phillips, R. L.: Paleoecology of lateglacial peats from the Bering land bridge, Chukchi Sea shelf region, northwestern Alaska, Quaternary Res., 38, 371-378, 1992.

Elvelhøi, A. and Rønningsland, T. M.: Semiquantitative calculation of the relative amounts of kaolinite and chlorite by X-ray diffraction, Mar. Geol., 27, M19-M23, https://doi.org/10.1016/00253227(78)90070-1, 1978.

Farmer, J. R., Cronin, T. M., de Vernal, A., Dwyer, G. S., Keigwin, L. D., and Thunell, R. C.: Western Arctic Ocean temperature variability during the last 8000 years, Geophys. Res. Lett., 38, L24602, https://doi.org/10.1029/2011GL049714, 2011.

Fisher, D., Osterberg, E., Dyke, A., Dahl-Jensen, D., Demuth, M., Zdanowicz, C., Bourgeois, J., Koerner, R. M., Mayewski, P., Wake, C., Kreutz, K., Steig, E., Zheng, J., Yalcin, K., Goto-Azuma, K., Luckman, B., and Rupper, S.: The Mt Logan Holocene-late Wisconsinan isotope record: tropical PacificYukon connections, Holocene, 18, 667-677, 2008.

Frey, K. E., Perovich, D. K., and Light, B.: The spatial distribution of solar radiation under a melting Arctic sea ice cover, Geophys. Res. Lett., 38, L22501, https://doi.org/10.1029/2011GL049421, 2011.

Funder, S., Goosse, H., Jepsen, H., Kaas, E., Kjær, K. H., Korsgaard, N.J., Larsen, N. K., Linderson, H., Lyså, A., Möller, P., Olsen, J., and Willerslev, E.: A 10,000-year record of Arctic Ocean sea-ice variability - View from the beach, Science, 333, 747-750, 2011.

Giles, K. A., Laxon, S. W., Ridout, A. L., Wingham, D. J., and Bacon, S.: Western Arctic Ocean freshwater storage increased by 
wind-driven spin-up of the Beaufort Gyre, Nat. Geosci., 5, 194197, 2012.

Godfrey, J. S.: A sverdrup model of the depth-integrated flow for the ocean allowing for island circulations, Geophys. Astro. Fluid, 45, 89-112, 1989.

Griffin, G. M. and Goldberg, E. D.: Clay mineral distributions in the Pacific Ocean, in: The sea, III, edited by: Hill, M. N., 728-741, Interscience Pub., New York, USA, 1963.

Gudkovitch, Z. M.: On the nature of the Pacific current in Bering Strait and the cause of its seasonal variations, Deep-Sea Res., 9, 507-510, 1962.

Harada, N.: Review: Potential catastrophic reduction of sea ice in the western Arctic Ocean: its impact on biogeochemical cycles and marine ecosystems, Global Planet. Change, 136, 1-17, 2016.

Hu, C., Henderson, G. M., Huang, J., Xie, S., Sun, Y., and Johnson, K. R.: Quantification of Holocene Asian monsoon rainfall from spatially separated cave records, Earth Planet. Sc. Lett., 266, 221-232, 2008.

Jakobsson, M., Pearce, C., Cronin, T. M., Backman, J., Anderson, L. G., Barrientos, N., Björk, G., Coxall, H., de Boer, A., Mayer, L. A., Mörth, C.-M., Nilsson, J., Rattray, J. E., Stranne, C., Semiletov, I., and O'Regan, M.: Post-glacial flooding of the Bering Land Bridge dated to $11 \mathrm{cal} \mathrm{kaBP}$ based on new geophysical and sediment records, Clim. Past, 13, 991-1005, https://doi.org/10.5194/cp-13-991-2017, 2017.

Kalinenko, V. V.: Clay minerals in sediments of the Arctic Seas, Lith. Min. Res. 36, 362-372, translated from: Litologiya I Poleznye Iskopaemye, 4, 418-429, 2001.

Katsuki, K., Khim, B.-K., Itaki, T., Harada, N., Sakai, H., Ikeda, T., Takahashi, K., Okazaki, Y., and Asahi, H.: Land-sea linkage of Holocene paleoclimate on the Southern Bering Continental Shelf, The Holocene, 19, 747-756, 2009.

Kaufman, D. S., Axford, Y. L., Henderson, A. C. G., McKay, N. P., Oswald, W. W., Saenger, C., Anderson, R. S., Bailey, H. L., Clegg, B., Gajewski, K., Hu, F. S., Jones, M. C., Massa, C., Routson, C. C., Werner, A., Wooller, M. J., and Yu, Z.: Holocene climate changes in eastern Beringia (NW North America) - a systematic review of multi-proxy evidence, Quaternary Sci. Rev., 147, 312-339, 2016.

Keigwin, L. D., Donelly, J. P., Cook, M. S., Driscoll, N. W., and Brigham-Grette, J.: Rapid sea-level rise and Holocene climate in the Chukchi Sea, Geology, 34, 861-864, 2006.

Kobayashi, D., Yamamoto, M., Irino, T., Nam, S.-I., Park, Y.-H., Harada, N., Nagashima, K., Chikita, K., and Saitoh, S.-I.: Distribution of detrital minerals and sediment color in western Arctic Ocean and northern Bering Sea sediments: Changes in the provenance of western Arctic Ocean sediments since the last glacial period, Polar Science, 10, 519-531, 2016.

Leduc, G., Vidal, L., Tachikawa, K., Rostek, F., Sonzogni, C., Beaufort, L., and Bard, E.: Moisture transport across Central America as a positive feedback on abrupt climatic changes, Nature, 445 , 908-911, https://doi.org/10.1038/nature05578, 2007.

Lee, S. H. and Whitledge, T. E.: Primary and new production in the deep Canada Basin during summer 2002, Polar Biology, 28, 190-197, 2005.

Lisé-Pronovost, A., St-Onge, G., Brachfeld, S., Barletta, F., and Darby, D.: Paleomagnetic constraints on the Holocene stratigraphy of the Arctic Alaskan margin, Global Planet. Change, 68, 85-99, 2009.
McKay, J. L., de Vernal, A., Hillaire-Marcel, C., Not, C., Polyak, L., and Darby, D.: Holocene fluctuations in Arctic sea-ice cover: dinocyst-based reconstructions for the eastern Chukchi Sea, Can. J. Earth Sci., 45, 1377-1397, 2008.

McNeely, R., Dyke, A. S., and Southon, J. R.: Canadian marine reservoir ages, preliminary data assessment, Open File Report - Geological Survey of Canada, 5049, no. 3, Ottawa, Canada, 2006.

Miller, G. H., Alley, R. B., Brigham-Grette, J., Fitzpatrick, J. J., Polyak, L., Serreze, M. C., and White, J. W. C.: Arctic amplification: can the past constrain the future?, Quaternary Sci. Rev., 29, 1779-1790, 2010.

Müller, G.: Methods in Sedimentary Petrology, Scweizerbart Science Publishers, 283 pp., Stuttgart, Germany, 1967.

Naidu, A. S. and Mowatt, T. C.: Sources and dispersal patterns of clay minerals in surface sediments from the continental shelf areas off Alaska, Geol. Soc. Am. Bull., 94, 841-854, 1983.

Naidu, A. S., Creager, J. S., and Mowatt, T. C.: Clay mineral dispersal patterns in the North Bering and Chukchi Seas, Mar. Geol., 47, 1-15, 1982.

Nishihara, M., Morri, H., and Koga, Y.: Structure determination of a quartet of novel tetraether lipids from Methanobacterium thermoautotrophicum, J. Biochem., 101, 1007-1015, 1987.

Nishino, S., Shimada, K., Itoh, M., and Chiba, S.: Vertical double silicate maxima in the sea-ice reduction region of the western Arctic Ocean: implications for an enhanced biological pump due to sea-ice reduction, J. Oceanogr., 60, 871-883, 2009.

Nwaodua, E., Ortiz, J. D., and Griffith, E. M.: Diffuse spectral reflectance of surficial sediments indicates sedimentary environments on the shelves of the Bering Sea and western Arctic, Mar. Geol., 355, 218-233, 2014.

Olsen, J., Anderson, N. J., and Knudsen, M. F.: Variability of the North Atlantic Oscillation over the past 5200 years, Nat. Geosci., 5, 808-812, 2012.

Ortiz, J. D., Polyak, L., Grebmeier, J. M., Darby, D., Eberl, D. D., Naidu, S., and Nof, D.: Provenance of Holocene sediment on the Chukchi-Alaskan margin based on combined diffuse spectral reflectance and quantitative X-Ray Diffraction analysis, Global Planet. Change, 68, 73-84, 2009.

Ortiz, J. D., Nof, D., Polyak, L., St-Onge, G., Lisé-Pronovost, A., Naidu, S., Darby, D., and Brachfeld, S.: The late Quaternary flow through the Bering Strait has been forced by the Southern Ocean winds, J. Phys. Oceanogr., 42, 2014-2029, 2012.

Osterberg, E. C., Mayewski, P. A., Fisher, D. A., Kreutz, K. J., Maasch, K. A., Sneed, S. B., and Kelsey, E.: Mount Logan ice core record of tropical and solar influences on Aleutian Low variability: 500-1998 A.D., J. Geophys. Res.-Atmos., 119, 11189_ 11204, https://doi.org/10.1002/2014JD021847, 2014.

Overland, J. O., Adams, J. M., and Bond, N.: Decadal variability of the Aleutian Low and its relation to high-latitude circulation, J. Climate, 12, 1542-1548, 1999.

Paillard, D., Labeyrie, L., and Yion, P.: Macintosh program performs time-series analysis, EOS Trans. AGU 77, Washington, D.C., USA, p. 379, 1996.

Park, Y.-H., Yamamoto, M., Polyak, L., and Nam, S.-I.: Glycerol dialkyl glycerol tetraether variations in the northern Chukchi Sea, Arctic Ocean, during the Holocene, Biogeosciences Discuss., https://doi.org/10.5194/bg-2016-529, 2016. 
Petschick, R.: MacDiff 4.2.6., available at: http://www.geol-pal. uni-frankfurt.de/Staff/Homepages/Petschick/classicsoftware. html (last access: 2 September 2017), 2000.

Phillips, R. P. and Grantz, A.: Regional variations in provenance and abundance of ice-rafted clasts in Arctic Ocean sediments: implications for the configuration of late Quaternary oceanic and atmospheric circulation in the Arctic, Mar. Geol. 172, 91-115, 2001.

Pickart, R. S.: Shelfbreak circulation in the Alaskan Beaufort Sea: Mean structure and variability, J. Geophys. Res. 109, C04024, https://doi.org/10.1029/2003JC001912, 2004.

Pickart, R. S., Pratt, L. J., Torres, D. J., Whitledge, T. E., Proshutinsky, A. Y., Aagaard, K., Agnewd, T. A., Moore, G. W. K., and Dail, H. J.: Evolution and dynamics of the flow through Herald Canyon in the western Chukchi Sea, Deep-Sea Res. Pt. II, 57, 5-26, 2010.

Polyak, L., Bischof, J., Ortiz, J. D., Darby, D. A., Channell, J. E. T., Xuan, C., Kaufman, D. S., Løvile, R., Schneider, D., Eberl, D. D., Adler, R. E., and Council, E. A.: Late Quaternary stratigraphy and sedimentation patterns in the western Arctic Ocean, Global Planet. Change, 68, 5-17, 2009.

Polyak, L., Belt, S., Cabedo-Sanz, P., Yamamoto, M., and Park, Y.H.: Holocene sea-ice conditions and circulation at the ChukchiAlaskan margin, Arctic Ocean, inferred from biomarker proxies, The Holocene, 26, 1810-1821, 2016.

Porter, S. E.: Assessing whether climate variability in the Pacific Basin influences the climate over the North Atlantic and Greenland and modulates sea ice extent, $\mathrm{PhD}$ Thesis, Ohio State University, Columbus, USA, 222 pp., 2013.

Proshutinsky, A. Y. and Johnson, M. A.: Two circulation regimes of the wind-driven Arctic Ocean, J. Geophys. Res., 102, 12493 12514, 1997.

Qin, W., Amin, S. A., Martens-Habbena, W., Walker, C. B., Urakawa, H., Devol, A. H., Ingalls, A. E., Moffett, J. M., Armbrust, E. V., and Stahl, D. A.: Marine ammonia-oxidizing achaeal isolates display obligate mixotrophy and wide ecotypic variation, P. Natl. Acad. Sci. USA, 111, 12504-12509, 2014.

Reimer, P. J., Bard, E., Bayliss, A., Beck, J. W., Blackwell, P. G., Ramsey, C. B., Buck, C. E., Cheng, H., Edwards, R. L., Friedrich, M., Grootes, P. M., Guilderson, T. P., Haflidason, H., Hajdas, I., Hatté, C., Heaton, T. J., Hoffmann, D. L., Hogg, A. G., Hughen, K. A., Kaiser, K. F., Kromer, B., Manning, S. W., Niu, M., Reimer, R. W., Richards, D. A., Scott, E. M., Southon, J. R., Staff, R. A., Turney, C. S. M., and van der Plicht, J.: Intcal13 and Marine13 radiocarbon age calibration curves 0-50 000 years cal BP, Radiocarbon, 55, 1869-1887, 2013.

Richter, I. and Xie, S.: Moisture transport from the Atlantic to the Pacific basin and its response to North Atlantic cooling and global warming, Clim. Dynam., 35, 551-566, https://doi.org/10.1007/s00382-009-0708-3, 2010.

Rigor, I. G., Wallace, J. M., and Colony, R. L.: Response of sea ice to the Arctic Oscillation, J. Climate, 15, 2648-2663, 2002.

Rimbu, N., Lohmann, G., Kim, J.-H., Arz, H. W., and Schneider, R.: Arctic/North Atlantic Oscillation signature in Holocene sea surface temperature trends as obtained from alkenone data, Geophys. Res. Lett., 30, 1280, https://doi.org/10.1029/2002GL016570, 2003.

Roach, A. T., Aagaard, K., Pease, C. H., Salo, S. A., Weingartner, T., Pavlov, V., and Kulakov, M.: Direct measurements of trans- port and water properties through Bering Strait, J. Geophys. Res., 100, 18433-18457, 1995.

Sagawa, T., Kuwae, M., Tsuruoka, K., Nakamura, Y., Ikehara, M., and Murayama, M.: Solar forcing of centennial-scale East Asian winter monsoon variability in the mid-to late Holocene, Earth Planet. Sc. Lett., 395, 124-135, 2014.

Sakshaug, E.: Primary and secondary production in the Arctic ocean, in: The Organic Carbon Cycle in the Arctic Ocean, edited by: Stein, R. and Macdonald, R. W., Springer, Berlin, Germany, 57-81, 2004.

Sandal, C. and Nof, D.: The Collapse of the Bering Strait Ice Dam and the Abrupt Temperature Rise in the Beginning of the Holocene, J. Phys. Oceanogr., 38, 1979-1991, 2008.

Sarnthein, M., Gebhardt, H., Kiefer, T., Kucera, M. Cook, M., and Erlenkeuserd, H.: Mid Holocene origin of the sea-surface salinity low in the subarctic North Pacific, Quaternary Sci. Rev., 23, 2089-2099, 2004.

Screen, J. A. and Simmonds, I.: The central role of diminishing sea ice in recent Arctic temperature amplification, Nature, 464 1334-1337, 2010.

Shimada, K., Carmack, E., Hatakeyama, K., and Takizawa, T.: Varieties of shallow temperature maximum waters in the Western Canadian Basin of the Arctic Ocean, Geophys. Res. Lett., 28, 3441-3444, 2001.

Shimada, K., Kamoshida, T., Itoh, M., Nishino, S., Carmack, E., McLaughlin, F., Zimmermann, S., and Proshutinsky, A.: Pacific Ocean inflow: Influence on catastrophic reduction of sea ice cover in the Arctic Ocean, Geophys. Res. Lett., 33, L08605, https://doi.org/10.1029/2005GL025624, 2006.

Shtokman, V. B.: Vliyanie vetra na techeniya v Beringovo Prolive, prichiny ikh bol'shikh skorostei i preobladayueshego severnogo napravleniya, Trans. Inst. Okeanolog., Akad. Nauk SSSR, 25, 171-197, 1957.

Singh, H. K. A., Donohoe, A., Bitz, C. M., Nusbaumer, J., and Noone, D. C.: Greater aerial moisture transport distances with warming amplify interbasin salinity contrasts. Geophys. Res. Lett. 43, 8677-8684, https://doi.org/10.1002/2016GL069796, 2016.

Stein, R.: Developments in Marine Geology: Arctic Ocean Sediments: Processes, Proxies, and Paleoenvironment, Elsevier, Amsterdam, the Netherlands, 529 pp., 2008.

Stein, R., Fahl, K., Schade, I., Nanerung, A., Wassmuth, S., Niessen, F., and Nam, S.-I.: Holocene variability in sea ice cover, primary production, and Pacific-Water inflow and climate change in the Chukchi and East Siberian Seas (Arctic Ocean), J. Quaternary Sci., 32, 362-379, 2017.

Steinhilber, F., Beer, J., and Fröhlich, C.: Total solar irradiance during the Holocene, Geophys. Res. Lett., 36, L19704, https://doi.org/10.1029/2009GL040142, 2009.

Steinman, B. A., Abbott, M. B., Mann, M. E., Ortiz, J. D., Feng, S., Pompeani, D. P., Stansell, N. D., Anderson, L., Finney, B. P., and Bird, B. W.: Ocean-atmosphere forcing of centennial hydroclimate variability in the Pacific Northwest, Geophys. Res. Lett., 41, 2553-2560, https://doi.org/10.1002/2014GL059499, 2014.

Stigebrandt, A.: The North Pacific: A global-scale estuary, J. Phys. Oceanogr., 14, 464-470, 1984.

Vare L. L., Masse G., and Gregory, T. R.: Sea ice variations in the central Canadian Arctic Archipelago during the Holocene, Quaternary Sci. Rev., 28, 1354-1366, 2009. 
Viscosi-Shirley, C., Mammone, K., Pisias, N., and Dymond, J.: Clay mineralogy and multi-element chemistry of surface sediments on Siberian-Arctic shelf: implications for sediment provenance and grain size sorting, Cont. Shelf Res., 23, 1175-1200, 2003.

Vogt, C.: Regional and temporal variations of mineral assemblages in Arctic Ocean sediments as climatic indicator during glacial/interglacial changes, Reports on Polar Research, 251, 1309, 1997.

Volkman, J. K.: A review of sterol markers for marine and terrigenous organic matter, Org. Geochem., 9, 83-99, 1986.

Wahsner, M., Müller, C., Stein, R., Ivanov, G., Levitan, M., Shekekhova, E., and Tarasov, G.: Clay-mineral distribution in surface sediments of Eurasian Arctic Ocean and continental margin as indicator for source areas and transport pathways - a synthesis, Boreas, 28, 216-233, 1999.

Walsh, J. J. and Dieterle, D. A.: $\mathrm{CO}_{2}$ cycling in the coastal ocean. I. A numerical analysis of the southeastern Bering Sea, with applications to the Chukchi sea and the northern Gulf of Mexico, Prog. Oceanogr., 34, 335-392, 1994.
Watanabe, E., Onodera, J., Harada, N., Honda, M., Kimoto, K., Kikuchi, T., Nishino, S., Matsuno, K., Yamaguchi, A., Ishida, A., and Kishi, J. M.: Enhanced role of eddies in the Arctic marine biological pump, Nat. Commun., 5, 3950, https://doi.org/10.1038/ncomms4950, 2014.

Weingartner, T., Aagaard, K., Woodgate, R., Danielson, S., Sasaki, Y., and Cavalieri, D.: Circulation on the north central Chukchi Sea shelf, Deep-Sea Res. Pt. II, 52, 3150-3174, 2005.

Winsor, P. and Chapman, D. C.: Pathways of Pacific water across the Chukchi Sea: A numerical model study, J. Geophys. Res., 109, C03002, https://doi.org/10.1029/2003JC001962, 2004.

Woodgate, R. A., Weingartner, T. J., and Lindsay, R.: Observed increases in Bering Strait fluxes from the Pacific to the Arctic from 2001 to 2011 and their impacts on the Arctic Ocean water column, Geophys. Res. Lett., 39, L24603, https://doi.org/10.1029/2012GL054092, 2012.

Yamamoto-Kawai, M., Carmack, E., and McLaughlin, F.: Nitrogen balance and Arctic throughflow, Nature, 443, p. 43, https://doi.org/10.1038/443043a, 2006. 